\title{
ORIGIN AND CONCENTRATION: CORPORATE OWNERSHIP, CONTROL AND PERFORMANCE
}

\author{
Jan Hanousek \\ Evžen Kočenda \\ Jan Švejnar
}
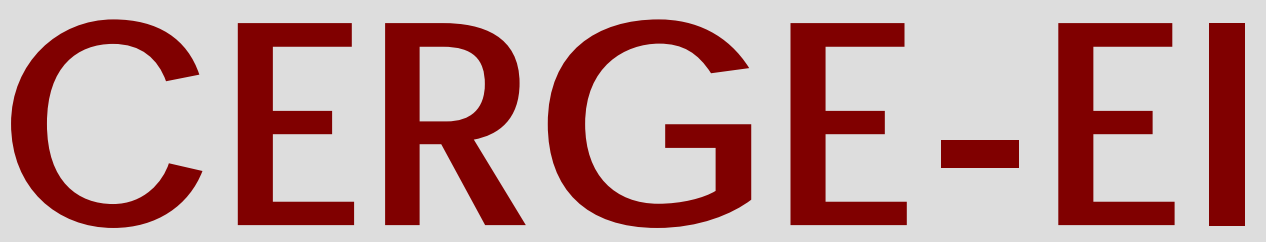

Charles University Centerfor Ec onomic Research and Graduate Education Academy of Sciences of the Czech Republic Ec onomic s Institute 


\title{
Working Paper Series $\quad 259$ (ISSN 1211-3298)
}

\section{Origin and Concentration: Corporate Ownership, Control and Performance}

\author{
Jan Hanousek \\ Evžen Kočenda \\ Jan Švejnar
}

CERGE-EI

Prague, May 2005 
ISBN 80-7343-048-7 (Univerzita Karlova v Praze, CERGE)

ISBN 80-7344-037-7 (Národohospodářský ústav AV ČR, Praha) 


\title{
Origin and Concentration: Corporate Ownership, Control and Performance
}

\author{
Jan Hanousek* \\ Evzen Kočenda* \\ Jan Švejnar**
}

May 2005

\begin{abstract}
We analyze the effects of different types and concentration of ownership on performance using a population of firms in a model transition economy after mass privatization. Specifications based on first-differences and unusual instrumental variables show that contrary to conventional wisdom, the effects of privatization and different types of ownership are limited and many types of private owners do not generate performance that is different from that of firms with state ownership. Concentrated ownership has a positive effect but only in some instances and a positive effect of foreign ownership is detectable primarily for majority ownership and foreign industrial firms. The effects of concentrated ownership support the agency theory and go against theories stressing the positive effects of managerial autonomy. Our results are also consistent with managers or stockholders "looting" the firms. The state as a holder of the golden share has a positive effect on employment and in some specifications also on output and profitability. Overall, our results suggest that the expectations and earlier findings of positive effects of privatization on performance were premature, with the effects of many types of ownership being indistinguishable from that of state ownership.
\end{abstract}

\begin{abstract}
Abstrakt
V tomto článku analyzujeme vliv různých typů a koncentrace vlastnictví na výkonnost podniků privatizovaných ve velké privatizaci. Vztah vlastnictví a výkonnosti firem modelujeme za pomocí prvních diferencí a vhodných instrumentálních proměnných. Naše výsledky ukazují, že na rozdíl od zažitých názorů je efekt privatizace a různých typů vlastnictví poměrně omezený a mnohé typy soukromého vlastnictví jsou v podstatě neodlišitelné svým vlivem na výkonnost od vlastnictví státního. Koncentrované vlastnictví vykazuje kladný vliv, avšak pouze v určitých případech měřené výkonnosti, a rovněž kladný efekt zahraničního vlastníka je pozorován primárně v př́padech majoritního vlastnictví v průmyslových podnicích. Stát jakožto vlastník zlaté akcie má kladný vliv zaměstnanost a v některých př́padech rovněž na velikost výroby a ziskovost. Celkově naše výsledky ukazují, že kladný vliv privatizace a následného soukromého vlastnictví na výkonnost podniků nejsou tak jednoznačné jak ukazovaly dřivější práce v této oblasti.
\end{abstract}

Keywords: ownership, performance, privatization, corporate governance, panel data, endogeneity, industrial organization

JEL Classification: C33, D20, G32, G34, L20

\footnotetext{
* CERGE-EI, Prague; CEPR, WDI

** University of Michigan Business School and Department of Economics, University of Michigan; CERGE-EI, CEPR, IZA, WDI

We would like to thank Juraj Valachy for valuable research assistance. We are indebted for valuable comments to Saul Estrin, Merritt Fox, Nandini Gupta, Gábor Kezdi, Jan Kmenta, János Kollo, Joep Konings, David Levine, Lubomír Lízal, Yingui Qian, Gérard Roland, and Klara Sabirianova. The paper also benefited from presentations at the Meetings of the American Economic Association, CEPR-WDI Conference on Transition Economics (Riga), LACEA Conference (Madrid), Indiana University, University of California at Berkeley, University of Michigan, University of Paris-Dauphine, University of Pennsylvania, and Catholic University of Leuven. Hanousek and Kočenda hold Citibank Professorships at CERGE-EI, a joint workplace of Charles University and the Academy of Sciences of the Czech Republic.
} 


\section{Introduction}

One of the fundamental and most controversial economic questions is whether private firms perform better than state-owned enterprises (SOEs) and whether privatization improves corporate performance. There is now a large literature on this subject, and the issue has gained currency as large-scale privatizations have taken place in many of the former command economies and developing countries. The issue is also of interest because the most populous and rapidly growing countries, China and India, are in the process of privatizing and others, such as Vietnam, are getting ready to privatize their SOEs.

Interestingly, while the premise and conclusions of initial studies with respect to privatization is that it improves firm performance and helps countries grow, the effect has not been clearly established. At the macro level, one observes that some of the fastest large-scale privatizers (e.g., Russia, Ukraine and the Czech Republic) experienced a decline or slow growth after privatization in the 1990s, while some of the fastest growing transition economies in the 1990s (e.g., China, Poland and Slovenia) were among the slowest to privatize. In a cross-country aggregate study, Sachs, Zinnes and Eilat (2000) find that privatization does not by itself increase GDP growth, but they suggest that a positive effect is present when privatization is accompanied by in-depth institutional reforms. Careful micro-econometric studies date back to Caves and Christensen's (1980) classic study that found private and state-owned Canadian railways performing equally efficiently in a head-on competition. Recent surveys of privatization studies based on micro data come up with assessments that range from finding a large variation of outcomes but no systematically significant effect of privatization on performance (Bevan, Estrin and Schaffer, 1999), to cautiously concluding that privatization around the world improves firm performance (Megginson and Netter, 2001), to being fairly confident that privatization tends to improve performance (Shirley and Walsh, 2000, and Djankov and Murrell, 2002). ${ }^{1}$

Apart from being somewhat diverse, the estimated performance effects found in much of the literature are not firmly established. The credibility issue arises from three types of interrelated analytical problems that may be expected to be present in early studies, especially those in the context of the rapidly changing transition economies. First, the early studies rely on short time periods with observations concentrated immediately before and after privatization. They may hence at best capture the short-term effects of 
privatization rather than the medium and long-term effects of a switch from state to private or mixed ownership. Second, the early studies (a) use small and often unrepresentative samples of firms, (b) are frequently unable to identify accurately ownership because privatization is still ongoing or because the frequent post-privatization changes of ownership are hard to detect, and (c) often combine panel data from different accounting systems. ${ }^{2}$ Third, many of the early studies are not been able to control adequately for endogeneity of ownership (firms not being selected for privatization at random), and their estimates of the effects of privatization may hence be biased (Gupta, Ham and Svejnar, 2000). ${ }^{3}$

Moreover, many of the early studies had access to limited data on firm ownership. ${ }^{4}$ As a result, they often treat ownership as a relatively simple categorical concept (e.g., private v. state or state v. foreign, domestic private outsider v. domestic private insider), and they are often unable to distinguish the exact extent of ownership by individual owners or even relatively homogeneous groups of owners. As we discuss below, this also prevents many studies from providing evidence for a lively debate about the desirability of concentrated versus dispersed ownership on corporate performance. ${ }^{5}$

In this paper we advance the literature by addressing systematically the three types of above-mentioned problems found in the existing studies. In particular, in analyzing the performance effects of ownership, we (a) use panel data on a complete population of medium and large firms that went through the natural experiment of mass privatization in a model economy (Czech Republic) and that constitute the bulk of the country's economic

\footnotetext{
${ }^{1}$ See Roland for a theoretical analysis and overview of privatization in transition.

${ }^{2}$ The key studies are indeed based on small samples related to short periods around privatization. For example, Frydman, Gray, Hessel and Rapaczynski (1999) use a 1990-93 sample of about 200 firms pooled from the Czech Republic, Hungary and Poland; D'Souza and Megginson (1999) analyze a total of 85 companies from 28 countries; Boubakri and Cosset (1998) use a 79 firm sample covering 29 countries; Barberis, Boycko, Shleifer, and Tsukanova (1996) use a sample of 260-340 Russian shops during the 199293 period; Bilsen and Konings (1998) use survey data for 1990-94 on about 260 firms divided among Bulgaria, Romania, and Hungary; Grosfeld and Nivet (1997) use a sample of 173 of the largest 500 companies in Poland during the 1988-1994 period; and Claessens and Djankov (1999) use data on approximately 700 manufacturing firms from the Czech Republic during 1993-97. See also Claessens (1997) and Filer and Hanousek (2002) for a discussion of these issues.

${ }^{3}$ Gupta et al.'s (2000) econometric evidence indicates that better performing firms tend to be privatized first. Moreover, as we indicate below, Djankov and Murrell's (2002) survey of studies dealing with the impact of privatization on performance indicates that one-half of the studies do not treat this issue at all. Our examination of the other half suggests that many treat the issue in a relatively haphazard way.

${ }^{4}$ See for example Pohl, Anderson, Claessens, and Djankov (1997), Smith, Cin, and Vodopivec (1997), Claessens and Djankov (1999), and Frydman, Hessel, and Rapaczynski (2000).

${ }^{5}$ An important recent exception is Grosfeld and Tressel (2001).
} 
activity, ${ }^{6}$ (b) cover a four-year period after privatization when accounting rules conforming to the international (IAP) standard were already in place and (c) control for endogeneity of ownership using a first-difference specification together with instrumental variables from rare data on pre-market initial conditions of these firms. Moreover, we also develop a more systematic analytical framework for evaluating the performance effect of post-privatization ownership and distinguish between instantaneous and permanent effects of ownership changes, and we use more detailed data on the extent of ownership by specific types of owners. ${ }^{7}$

The fact that we use data from a model transition economy that started almost completely state-owned and underwent virtually complete privatization means that we are analyzing a population of firms that experienced one of the greatest recorded changes in ownership. Since a number of other countries, including Russia, Ukraine, China, and Vietnam, have also started from almost complete public ownership, obtaining an understanding of the effects of the privatization process is of considerable interest. Unlike studies of partial privatization, we also benefit from a large variation in the values of the variables whose effect we analyze.

Finally, by carrying out a detailed study of one model economy, we are able to take into account specific legal and institutional features that relate to ownership and control, and avoid the problem of not being able to control adequately for complex cross-country differences in the institutional and legal frameworks that confront comparative studies with a limited number of country-specific observations. ${ }^{8}$

\footnotetext{
${ }^{6}$ Since we use data on the entire population of large and medium sized firms that went through privatization in the Czech Republic, one may think of our data as a country sample drawn from the population of centrally planned economies that went through mass privatization. The Central European economies have served as models for other transition countries in that early on they carried out important reforms and policy makers from other countries and international institutions such as the World Bank and the International Monetary Fund have used them as examples to follow. In this context, the Czech Republic has served as the example of rapid large-scale privatization in a previously unreformed and virtually completely state-owned economy, while Hungary has been the example of piece-meal privatization of individual firms in a previously reformed and partially privately owned economy.

${ }^{7}$ The present paper belongs to a second generation of studies that are being carried out to analyze corporate performance in the post-privatization period and employ large samples or populations of firm-level data from specific types of privatization in a given country. These studies are able to avoid some of the aforementioned problems and take into account specific institutional settings. Thus, Angelucci, Estrin, Konings and Zólkiewski (2002) use a large panel of manufacturing firms covering the years 1997-98 for Bulgaria and Romania, and 1994 and 1998 for Poland, Carlin, Fries, Schaffer and Seabright (2001) employ an EBRD cross-sectional survey of 3,300 firms in 25 transition countries and Lizal and Svejnar (2002) use 1992-98 panel data on the population of medium and large Czech industrial firms to examine investment behavior and the extent of credit rationing and soft budget constraints.

${ }^{8}$ The leading studies in this area (e.g., Boubakri and Cosset, 1998, Frydman et al., 1999, D’Souza and Megginson, 1999) are forced by the paucity of data to use pooled cross-country estimations.
} 
We find, contrary to expectations and results of many earlier studies, that the effects of privatization and different types of ownership on firm performance are very limited and that many types of private owners do not bring about performance that is different from that of firms with substantial state ownership. We do find some significant effects of specific types of private ownership. In particular, a positive effect of concentrated ownership is discernible but only in some instances and for selected performance indicators, and a positive effect of foreign ownership is detectable primarily in the case of majority ownership and appears to be driven by the behavior of foreign industrial firms. The concentrated foreign owners (industrial companies) yield superior performance compared to all other types of owners in terms of growth of sales and in some specifications also profitability (strategic restructuring), and concentrated domestic owners (industrial companies and investment funds) reduce employment relative to others (defensive restructuring).

The structure of the paper is as follows. In Section 2, we provide information on the privatization process that generates our data, while in Section 3 we discuss the relevant

features of the legal system and the hypothesized implications of different types of ownership on firm performance. In Section 4, we describe the data and basic statistics and in Section 5 we outline our empirical strategy. We present our empirical estimates in Section 6 and we draw conclusions in Section 7.

\section{Privatization in the Czech Republic}

The privatization program in the Czech Republic was carried out in the first half of the 1990s under three different schemes: restitution, small-scale privatization and largescale privatization. The first two schemes started in 1990 and were most important during the early years of the transition. Large-scale privatization, by far the most important scheme, began in 1991 and was completed in early 1995. ${ }^{9}$ The privatization program allowed various privatization techniques. Small firms were usually auctioned or sold in tenders. Many medium businesses were sold in tenders or to pre-determined buyers in direct sales. Most large and many medium firms were transformed into joint stock companies and their shares were distributed through voucher privatization, sold in public auctions or to strategic partners, or transferred to municipalities. 
The voucher scheme was part of the large-scale privatization process and it attracted considerable interest and publicity. ${ }^{10}$ Two waves of voucher privatization took place in 1992-93 and 1993-94, respectively. The early post-privatization ownership structure emerged as shares from the second wave were distributed in early 1995. Rapid reallocation of shares across new owners took place in 1995-96 during the so-called "third wave" of privatization as new owners, including the investment privatization funds (IPFs), reshaped their initial post-privatization portfolios of acquired companies. Depending on the investor, the swapping of shares in 1995-96 was aimed at (a) optimal portfolio diversification, (b) obtaining concentrated ownership in specific firms and industries and (c) achieving conformity with legal requirements aimed at preventing excessive stakes being held by privatization funds. ${ }^{11}$ The 1995-96 ownership changes were massive, unregulated and frequently unobservable to outsiders, including researchers. Investors, especially the IPFs, engaged in direct swaps of large blocks of shares, and off-market share trading was common. More stable and, from the standpoint of firm performance, more meaningful patterns of ownership emerged in 1996. We analyze the 1996-99 performance effects of various patterns of ownership and their changes after the dust of large-scale privatization and early post-privatization ownership swaps settled.

\section{Forms of Ownership and Hypothesized Effects on Performance}

\section{Concentrated or Dispersed Ownership?}

In addition to the debate about the merits of privatization and private v. public ownership, a major issue that has received renewed attention, without resulting in a consensus, is whether concentrated or dispersed ownership is more conducive to good corporate performance. The literature that focuses on the agency problem arising from the separation of ownership and control usually argues for the desirability of concentrated ownership because it results in superior monitoring of managers (who might otherwise loot

\footnotetext{
${ }^{9}$ The privatization process has been extensively described and analyzed. See e.g., Svejnar and Singer (1994), Kotrba (1995), Coffee (1996), and Kočenda (1999). For development of ownership structures in voucherprivatized firms, see Kočenda and Valachy (2002).

${ }^{10}$ The voucher scheme is sometimes erroneously referred to as the large-scale privatization program itself.

${ }^{11}$ The regulation of IPFs evolved gradually through Decree no. 383/1991, its Amendment No. 62/1992, and Act No. 248/1992. The most important clauses restricted each privatization fund from investing more than $10 \%$ of points acquired in the voucher scheme in a single company and obtaining in exchange more than $20 \%$ of shares in any company. Privatization funds established by a single founder were allowed to accumulate up to $40 \%$ of shares in a given company, but this cap was later reduced to $20 \%$. Many privatization funds circumvented the cap through mergers. The Act also prohibited IPFs founded by financial
} 
the firm) and hence maximization of shareholder value and availability of external finance for the firm (see e.g., a survey by Shleifer and Vishny, 1997). As Burkart, Gromb and Panunzi (2000) have shown, however, the agency problem may exist even when a large shareholder is present if this shareholder loots the firm at the expense of small shareholders. Governments and local shareholders have raised similar issues with respect to the potential dissipation of profits through transfer pricing by foreign firms.

On the other hand, models of asymmetric information and optimal delegation of authority (e.g., Aghion and Tirole, 1997) point to the importance of managerial initiative and incentives to acquire information, highlighting the fact that concentrated ownership with little delegation of formal authority to managers may be deleterious to firm performance. ${ }^{12}$ Similarly, the literature pioneered by Holmstrom and Tirole (1983) points out that concentrated ownership reduces market liquidity and hence lowers the benefits of market monitoring on corporate performance. Finally, Bolton and von Thadden (1998) argue that concentrated ownership may or may not be desirable, showing that an alternative is ownership dispersion with trading in secondary markets or ease of takeovers generating concentration whenever necessary for intervention in managerial decisionmaking. As we discuss below, from a government perspective, the idea of being able to intervene selectively when needed is incorporated in the mechanism of a golden share.

Since we are able to identify all owners with ownership stakes of 10 percent or more, we classify all firms into categories that allow us to test the validity of the competing predictions from the above theories. Depending on their stakes, different blockholders have different capacity to influence corporate governance. In particular, the Czech law provides important rights of ownership and control to owners with majority ownership (more than 50 percent of shares), blocking minority ownership (more than 33 percent but not more than 50 percent of shares) and what we define as legal minority ownership (at least 10 but not more than 33 percent of shares). Majority ownership grants the owner the right to staff management and supervisory boards, to alter and/or transfer firms' assets and to adopt most crucial strategic decisions at general shareholders' meetings. Through management and supervisory boards, majority ownership also facilitates more direct executive control of the company. The blocking minority ownership gives the right to block a number of decisions, such as those related to increasing or reducing assets and implementing major changes in financial capital (for details see Kotrba and Svejnar, 1994). 
business activities that the majority shareholder may strive to implement at the general shareholders' meeting. Finally, legal minority ownership can be considered a form of dispersed ownership since its concentration is low and its direct impact on routine business decisions is limited. Legal minority is potentially important, however, because the law entitles the holder of this stake to call the general shareholders' meeting and obstruct its decisions by delaying their implementation through lengthy court proceedings. Effective legal minority shareholders (including the state) may thus use their ownership position to delay or completely block the implementation of decisions by stronger shareholder(s). ${ }^{13}$

Overall, the majority and blocking minority represent different degrees of concentrated ownership, while the legal minority may be viewed as a form of moderately dispersed ownership. Highly dispersed ownership arises when the stake of the largest holder held does not reach legal (10 percent) minority. We are also able to distinguish whether the government keeps a golden share that gives it the right to veto certain managerial decisions, such as the subject of business activities and sales of assets, and indirectly influence all managerial decisions. Institutional evidence suggests that the golden share may be an important mechanism enabling the state to exert a degree of influence over firms in which it no longer holds a sufficient ownership stake. ${ }^{14}$

\section{Types of Ownership}

As mentioned earlier, most empirical work has focused on relatively broad categories of ownership. In this paper, we assess whether finer ownership distinctions that reflect different business activities of the owners provide a meaningful understanding of the effects of ownership on corporate performance. In particular, we examine the effects of six types of domestic and two types of foreign ownership that may have differing implications for corporate objectives, constraints and governance. The six types of

\footnotetext{
${ }^{14}$ See Grosfeld and Tressel (2001) for an articulation of this and the following interpretations.

${ }^{13}$ Interesting effect is observed in the case of portfolio companies that are primarily interested in capital gains. These companies have been observed to buy 10 percent positions in firms where they can sell the stake at a premium to the dominant shareholder whose business strategy is to avoid excessive scrutiny by an institutionally strong minority shareholder.

${ }^{14}$ The golden share was introduced by Act No. 210/1993, modifying Act No. 92/1991. The act set the conditions for property transfer from the state to others with the aim of protecting special interests of the state in firms privatized in large-scale privatization. The veto rights associated with the golden share usually relate to the scope and line of business activity and depend on each company's charter. When the state sells its golden share, it gives up its rights in the company and the golden share ceases to exist. The instrument of the golden share in the Czech Republic does not conform fully to that found in other countries since it is limited to being solely an instrument of state control and does not serve as a means of attracting free or less expensive credit.
} 
domestic owners are the state, industrial company, bank, investment fund, portfolio company, and individual, while the two types of foreign owners are an industrial company and all other foreign owners. ${ }^{15}$ Since the literature does not provide clear-cut predictions about the relative performance effects of these types of owners, we briefly outline plausible hypotheses based on other studies and local institutional context.

The state as an owner may pursue various goals, including economic efficiency, tax revenues, or social goals such as employment. The results of Gupta, Ham and Svejnar's (2000) analysis suggest that in the Czech case revenue maximization was important in the privatization phase but other goals, such as employment generation, were also important in the post-privatization phase when unemployment was on the rise. The ownership of a firm by an industrial company may be expected to increase profitability through cost cutting, integration of activities and expansion aimed at exploiting economies of scale. Bank ownership is expected to impose pressure on the firm's management to improve profitability (Cornelli, Portes, and Schaffer, 1996), ${ }^{16}$ while investment (mutual) funds are expected to pursue profitable opportunities and, when desirable, take significant equity positions. Funds may hence place emphasis on sound corporate governance and restructuring of firms. Portfolio companies in the Czech Republic are diversified investment vehicles that engage in business with both corporate and private customers. Their ownership positions in large firms are more limited than those of the funds, but the experience in advanced market economies indicates that portfolio companies often force management to become more profitable. Individual ownership is widely perceived to give the single residual claimant having strong incentives to monitor the management and achieve superior firm performance. Finally, in a country with low labor cost and favorable profit repatriation rules, foreign owners are expected to aim at generating profits and, if the local products can be sold through their global distribution network, also on increasing output and hence employment. The issue that arises is whether profits generated by firms with foreign owners are declared or hidden through transfer pricing. Naturally, in an

\footnotetext{
${ }^{15}$ Since insiders have not been important in the Czech Republic, we do not analyze this type of ownership. We also do not examine whether a given owner belongs to a larger ownership group. With considerable additional data collection, this could be an interesting topic for future research.

${ }^{16}$ Ownership involvement of Czech banks in other companies resembles the situation in Germany. Allen and Gale (1995), with reference to the German financial market, argue that the fact that the market for corporate control collapses when stock markets are thin could be made up for by the role of banks as delegated monitors holding equity and exercising their voting rights. Czech banks, with their numerous holdings, were given the above option. However, as shown by Lízal and Kočenda (2001), the newly-created banks also had a number of serious structural weaknesses.
} 
underdeveloped legal and institutional setting, any one type of ownership could be associated with managers or key shareholders looting the firms, directly or through transfer pricing.

\section{The Data and Basic Statistics}

\subsection{Performance Data}

We start our analysis by providing an understanding of whether corporate restructuring associated with different types of ownership occurs more in terms of revenue or cost (the two main components of profit). We do so by using the rate of change in sales revenue and in labor cost. ${ }^{17}$ Profitability is widely viewed as the best ultimate measure of corporate performance, and we use two measures of profitability as our dependent variables: the annual rate of change of operating profit on sales (profit/sales or return on sales) and the annual change in the return on assets (ROA), measured as the ratio of the change in operating profit between periods $t-1$ and $t$ to total assets in period $t-1$. By using the profit/sales ratio, we take advantage of the fact that this indicator is based on two flow measures that are less sensitive to inflation and accounting conventions than many other indicators. By using assets in period $t-1$ in calculating the change in ROA, our measure is not affected by the possible phenomenon of privatized companies simply writing off unproductive assets. $^{18}$

Combined with the estimating framework that we describe below, as well as theoretical and empirical results from other studies, the four indicators of performance give us an opportunity to generate a number of analytical insights. First, since wages in public and private firms in the Czech Republic moved in tandem (Munich, Svejnar, and Terrell, 2005), the relative rate of change of labor costs between public and private firms reflects primarily changes in employment. A comparison of the relative evolution of sales/labor cost hence yields a close approximation of the relative evolution of sales/employment, or labor productivity. ${ }^{19}$

\footnotetext{
${ }^{17}$ We do not use other measures of performance, such as material costs, because the sample size would be substantially reduced due to limited information on other variables in the data.

${ }^{18}$ Our measure would provide a biased indicator of a change in ROA, however, if productive assets were sold and, as a result, both assets and profit (rather than just assets) diminished. However, only about $5 \%$ of the firms in our sample actually reduced their assets and, as we discuss below, firms that substantially reduced assets were removed from our sample when we eliminated outliers.

${ }^{19}$ This is especially the case as we control for the industry in which the SOEs and private firms operate.
} 
Second, the four indicators permit us to draw inferences about the extent to which firms with different ownership engage in the two types of restructuring that have been viewed as key after privatization of SOEs -- defensive (reactive) and strategic restructuring. ${ }^{20}$ Defensive restructuring is primarily related to short-term measures, such as layoffs and reductions in wages, while strategic restructuring refers to deliberate investments in the development of firms' advantages, such as introducing new products and finding new markets, and it results in increased sales revenues and profits.

Third, by examining the simultaneous effects of different types of ownership on the change of sales, labor cost and profitability, we are able to draw tentative conclusions about the presence of phenomena such as looting of the firm, inefficiencies, non-labor costs, and non-sale income.

Our working data set contains 2,529-2,949 observations on an unbalanced panel of 1,371-1,540 medium and large firms from all economic sectors during the period 19961999. As we indicate in Table 1, the exact number of observations and firms varies slightly across the four performance indicators. The observations represent a cleaned data set from the entire population of firms that were listed on the Prague Stock Exchange (PSE) in 1996. Since virtually all large and medium-sized firms privatized in large-scale privatization were listed on PSE, the data set contains most of these firms. In addition to performance variables, our data set contains detailed measures of ownership structure, sector in which the firm operates and the firm's privatization history (including performance and institutional data from the pre-privatization period). The data sample was compiled by the authors from information provided by Aspekt, a commercial database, the PSE, The National Property Fund (the privatization agency) of the Czech Republic, and the Business Register of the Czech Republic.

It is well known that firm-level data from the transition and emerging market economies often suffer from accounting deficiencies and usually contain missing values and outlier observations that may bias the estimated coefficients (e.g., Filer and Hanousek, 2002). Firms operating in the Czech Republic started adopting international accounting (IAP) standards in 1992, and our discussions with international accounting firms located in the country indicate that this process was by and large completed in 1995. Our 1996-99 data are hence from a period in which IAP already dominated local accounting standards.

\footnotetext{
${ }^{20}$ See Aghion and Carlin (1996), Grosfeld and Roland (1997) and Aghion, Blanchard and Carlin (1997) for a discussion of these concepts.
} 
Moreover, the data are reported by firms that had to conform to the standards demanded since the mid 1990s by the main regulatory institutions, namely the PSE, the National Property Fund and the Czech National Bank. The data are hence relatively reliable and free of the accounting deficiencies that plague earlier studies.

We have adopted a three-step approach to handling missing observations and outliers in the original data set of $2648,2972,2682$, and 3050 , year-to-year rate of change observations for sales, labor cost, profit/sales, and ROA, respectively. First, we eliminated the few (rate of change) observations that were based on inconsistent values in the levels of variables, such as negative values of sales or labor cost. This resulted in 2644, 2972, 2679, and 3050 observations for the rate of change of sales, labor cost, profit/sales, and ROA, respectively.

Second, since the data still contained a number of observations with fairly extreme values, we examined the sensitivity of parameter estimates to the trimming of these extreme values of variables, identifying points where the results became relatively insensitive to further trimming. We found that the estimates ceased being sensitive to trimming at the point where the year-to-year rate of change in the performance indicators was constrained to the wide interval of $(-100 \%, 300 \%)$ for sales and labor costs, $(-300 \%$, $300 \%$ ) for profit over sales and $(-40 \%, 40 \%)$ for ROA. ${ }^{21}$ Imposing these wide limits led to a relatively modest reduction in the number of observations and resulted in 2592 observations for the rate of change in sales, 2949 for the rate of change in labor cost, 2168 for the rate of change in profit over sales, and 2905 for the change in ROA. We have used Heckman's (1979) procedure to correct for the possible sample selection bias brought about by the two-step data cleaning procedure. ${ }^{22}$

Third, we explored the possibility of creating a balanced data set with the same firm-year pairs across the four performance indicators. We found that this would require reducing the number of observations for the rate of change of sales, labor costs, profit over sales, and ROA, by 572 (22\%), 929 (31\%), 148 (7\%), and 885 (30\%), respectively, resulting in a sample with only 1210 firms and 2020 observations. We have deemed this further reduction in the number of observations to be excessively large and used the larger

\footnotetext{
${ }^{21}$ In contrast, the estimated coefficients change dramatically and non-monotonically as we add the outlying observations beyond this borderline to the sample.

${ }^{22}$ In particular, using the original set of observations we first ran a Heckman-type probit equation, predicting the probability that a given observation is included in the subsample on the basis of the following variables: the initial values of the performance indicators and their squares and products, as well as dummy variables capturing the presence of a given firm in a particular privatization wave.
} 
sample from step two above in our analysis. For comparison, we have generated Heckmancorrected estimates based on the balanced sub-sample and found them to be broadly similar to those based on the larger sample.

On average, within the four-year (1996-99) period we have data for three consecutive years to compute annual rates of change of performance variables (Table 1). ${ }^{23}$ In terms of the number of firms and observations, our sample is larger than samples used in previous and most ongoing studies in this area. More detailed summary statistics of performance indicators by ownership type and ownership extent are presented in appendix tables A1 and A2. We have also carried out a number of checks against official and private records to verify that our ownership information is reliable and that we hence meet the criticism of earlier privatization studies raised by Filer and Hanousek (2002).

\subsection{Ownership Data}

An important feature of our data is that it permits us to analyze the effect of ownership on performance using two measures of ownership. First, as in most studies, we evaluate the performance effects associated with different types of a single largest owner (SLO). In doing so, we have the advantage that we can distinguish among the aforementioned six domestic and two foreign types of SLOs. Second, we assign all owners into three categories that have figured prominently in the privatization debate and are widely believed to have different effects on corporate governance and performance -- state, domestic private and foreign ownership. Having included all owners in one of these three categories, we examine whether majority, blocking minority and legal minority ownership by each of these three groups of owners affects the firm's performance. ${ }^{24}$ With both specifications of ownership, we also assess if the state affects corporate performance by retaining a golden share that gives it the right to block certain managerial decisions.

As may be seen in Table 2, domestic industrial companies are the most frequent SLOs with 1,244 observations, followed by domestic investment funds (423 observations), domestic individuals (335) and the Czech state (174). Foreign industrial companies are by far the most frequent SLOs among the foreign investors (236 observations), with the total number of foreign SLO observations being 303. Ownership concentration, measured by the

\footnotetext{
${ }^{23}$ There are 34 sales and 28 labor cost observations for which the rate of growth is -1 . Hence, only a small number of firms ended production during the 1996-1999 period.

${ }^{24}$ In this analysis, we hence focus on the effects of majority and blocking or legal minority ownership irrespective of how many different owners of the same type comprise the majority or minority groups.
} 
average stake held by a SLO, is between 38 and 59 percent, which is rather high in comparison to ownership concentration in developed countries (Demsetz and Lehn, 1985) and it resembles more the continental European than Anglo-American ownership concentration patterns.

Foreign owners as a group tend to hold majority ownership stakes in the acquired firms (panel B of Table 2). The situation is just the opposite for domestic private owners and the state, both of whom have average stakes around 43-45 percent and display absolutely and relatively more cases of blocking and legal minority ownership than majority ownership. Moreover, the state retains a golden share primarily in firms in which it or domestic private owners are the SLO. Finally, there are 33 observations with highly dispersed ownership in the sense that no type of owner has even a legal (10 percent) minority ownership. These observations come from 25 firms that are larger than average in terms of total assets, but otherwise tend to have quite diverse characteristics. ${ }^{25}$

In panels $\mathrm{A}$ and $\mathrm{B}$ of Table 3, we present two transition matrices depicting how ownership changed between 1996 and 1999 by SLO and extent of ownership, respectively. The ownership of origin (1996) is listed in the rows on the left-hand side of each panel and the destination (1999) ownership is shown in the column headings on the top of each panel. In each row, the diagonal entry gives the percentage of companies that remained in the same ownership category, while the off-diagonal entries show the percentages of companies that switched from the original ownership given by the relevant row to the new ownership given by the relevant column. As may be seen from Panel A, the flows across the eight types of SLOs show that domestic and foreign industrial firms are stable types of owners in that 69 percent and 75 percent of firms that had SLOs in these two categories in 1996, respectively, had SLOs in the same categories also in 1999. Together with domestic investment funds and individually owned companies, these two ownership forms are also the main recipients of inflows of firms from other categories, especially domestic portfolio companies, banks and foreign other (non-industrial) firms. Indeed, domestic industrial companies become the most frequent new SLOs of firms from all the original categories of ownership, while foreign industrial companies take over as SLOs primarily from foreign non-industrial companies and banks. Domestic investment funds are a favorite SLO destination for firms from bank and portfolio company ownerships, while domestic 
individual owners become new SLOs relatively evenly across all the original ownership categories except for foreign industrial firms.

When measured by the extent of state, domestic private and foreign ownership (Panel B), majority foreign and majority domestic ownership forms are the most stable forms, retaining 73 percent and 68 percent of their 1996 firms in 1999. Majority domestic ownership, followed by blocking minority domestic ownership, are the two main ownership forms to which firms switched from almost all other categories. There was also a tendency toward concentration of foreign ownership as majority foreign ownership was a significant destination for firms with blocking and legal foreign minority ownership. Finally a significant proportion of firms with foreign ownership of all types switched to domestic majority or minority ownership over time.

Overall, we observe substantial ownership changes during the relatively stable post-privatization period under study. In terms of the categories in Table 3, 7 to 48 percent of our sample changed category by the type of SLO and 15 to 31 percent by extent of ownership, with the greatest (smallest) shift being toward an industrial company (bank) as the SLO. Data not reported here show that ownership changes were relatively evenly distributed over the 1996-99 period.

\section{The Econometric Model}

\subsection{Model Specification}

Our main goal is to analyze the performance effects of the principal types of ownership that we observe after the large-scale privatization in 1996. In addition, we want to control for and estimate the effects of the changes in ownership that took place in the 1996-99 post-privatization period that we analyze. In order to do so, we adapt the Ashenfelter and Card (1985) and Heckman and Hotz (1989) panel data treatment evaluation procedure for our context and supplement it with instrumental variables.

Let $X_{i j t}$ be a given performance indicator, with subscript $i$ denoting an individual firm with ownership type $j$, in year $t$, and let $y_{i j t}$ be the percentage change of $X_{i j t}$ from $t-1$ to $t$. Moreover, let $P_{i j t}$ denote ownership type $j$ of firm $i$ in year $t$. A logarithmic model of performance may be specified as

\footnotetext{
${ }^{25}$ The firms belong to various sectors, with 7 being in trade and 4 in construction and building materials sectors. In 5 firms foreign owners have the largest, albeit relatively small, stakes. The state holds the golden share in two of these firms, both of which are water supply utilities.
} 


$$
\ln X_{i j t}=\alpha_{i}+\alpha t+\left(P_{i j 1} t\right) \beta_{j}+\left(X_{i j 1} t\right) \gamma_{j}+P_{i j \tau} \delta_{j}+\left[P_{i j \tau}(t-\tau)\right] \theta_{j}+(D t) \varphi+v_{i j t},
$$

which may be expressed in the annual rate of change (first-difference) specification as an estimating equation ${ }^{26}$

$$
y_{i j t}=\alpha+P_{i j 1} \beta_{j}+X_{i j 1} \gamma_{j}+\Delta P_{i j \tau} \delta_{j}+P_{i j \tau} \theta_{j}+D \varphi+\varepsilon_{i j t}
$$

For ease of interpretation, all dummy variables in equation (2) are coded relative to the constant $\alpha$ which, depending on the specification of ownership, contains the performance effect of state SLO or state majority ownership. The column vector $\beta_{j}$ therefore reflects the effects of all the other types of 1996 post-privatization ownership $P_{i j 1}$ relative to state SLO or state majority ownership. ${ }^{27}$ Similarly, vector $\delta_{j}$ captures the instantaneous effect observed in any year $\tau$ after 1996 if a firm changed its 1996 ownership to a new ownership category $\Delta P_{i j \tau}$, and vector $\theta_{j}$ reflects the permanent effect associated with the new type of ownership $P_{i j \tau}$ established at time $\tau{ }^{28}$ Coefficients $\beta_{j}$ and $\theta_{j}$ hence give the initial and subsequent permanent effects of ownership and our principal goal is to obtain unbiased estimates of $\beta_{j}$ and to the extent possible also $\theta_{j}$. In estimating $\beta_{j}$ and $\theta_{j}$ in equation (2), we control for other factors that affect performance and may be correlated with ownership. Thus vector $\alpha_{i}$ controls for firm-specific (fixed effect) differences in performance across firms, vector $\gamma_{j}$ reflects the effect of initial postprivatization level of performance $X_{i j l}$ on the future rate of change of performance, and vector $\varphi$ represents the effect of $D$, industry and annual dummy variables as well as dummy variables reflecting the form of privatization of the firm (first or second wave, both waves, or outside of the voucher scheme). Finally, $\varepsilon_{i j t}=v_{i j t}-v_{i j t-1}$ is the error term.

Our specification thus controls for the effects on the rate of change of performance of fixed differences among firms that were or were not part of the voucher scheme, inter-

\footnotetext{
${ }^{26}$ Equation (2) may also be viewed as coming from a framework such as that invoked in the endogenous growth literature (e.g., Temple, 1999; Barro and Sala-i-Martin, 1995), where the rate of change of the dependent variable may depend on its initial level (e.g., rate of change of performance being related to an initial level of investment) and some other variables. In the context of the debate about the performance effects of ownership v. competition, we focus on estimating the effects of ownership, while controlling for the extent of competition by the firm-specific fixed effects, the effect of initial performance interacted with the time trend, and the industry-specific and annual time dummy variables interacted with time.

${ }^{27}$ Equivalently, the coefficients $\beta_{j}$ may be interpreted as the linearly time-varying effects of various non-state types of ownership, relative to SLO or majority state ownership, on the (log) level of corporate performance. Coding the ownership dummy variables so that the effects of non-state ownership forms is measured relative to the effect of state ownership is useful because firms in which the state retains ownership are the ones that are least privatized and under the null hypothesis also least restructured. The approach also accords with our desire to investigate change in performance as firms switch from state to private ownership.
} 
firm differences in the initial post-privatization performance, annual economy-wide shifts (such as macro shocks or degree of openness to trade) and industry-specific fixed effects (proxying for factors such as the degree of competition or differences in technology). In the context of the debate about the performance effects of ownership versus competition, we focus on estimating the effects of ownership, while controlling for competition by the firm-specific fixed effects, the effect of initial performance interacted with the time trend, and the industry-specific and annual time dummy variables interacted with time.

In addition to worrying about omitted variables bias, which we address by including the various control variables, we consider two other key econometric issues, measurement error and endogeneity (selection) of ownership. Measurement errors in ownership and performance, as well as other variables, can induce standard attenuation as well as more complicated biases in estimated coefficients. As discussed above, the earlier studies of privatization often suffer from mis-measurement of the ownership variables and performance indicators, including outliers that may seriously affect the estimated coefficients. In collecting the present data set, we have placed particular emphasis on identifying precisely individual owners and changes in ownership, as well as collecting several indicators of performance from a period when the IAP accounting system was in place. We have also tested for and eliminated outliers that affect the estimates.

Endogeneity (selection) of ownership is another serious issue. Gupta et al. (2000) find that better performing firms tend to be privatized first and since most studies compare the performance of privatized firms to that of firms that are still in state ownership, there is a danger that the inherently superior performance of the firms selected for privatization is attributed to privatization rather than the selection. Djankov and Murrell's (2002) survey of studies dealing with the impact of privatization on performance indicates that one-half of the studies do not treat this issue at all. Our examination of the other half suggests that many treat the issue in a relatively haphazard way. In the present study, we address this problem as follows. First, we use the first-difference specification in equation (2) with the aforementioned covariates as a panel data treatment evaluation procedure to control for the possibility that firms are not assigned to different ownership categories at random and that certain types of owners (e.g., foreigners) may acquire firms that are inherently superior or

\footnotetext{
${ }^{28}$ The term "permanent" effect is used to denote the effect that our data predict would last period after period and it distinguishes this effect from the one-year instantaneous effect.
} 
inferior performers. ${ }^{29}$ Second, since first-differencing does not fully address all types of endogeneity, especially those where the effect is time-varying, we also employ an instrumental variable strategy.

\subsection{Instrumental Variables}

Unlike other studies, we use a unique set of firm-specific instrumental variables from the pre-privatization (pre-1992) period. The instrumental variables reflect economic, institutional, industry, and geographic characteristics of the SOEs in the pre-market period, and we use them to instrument the initial post-privatization ownership that we observe in the market economy in 1996.

For each firm we have collected detailed information from all the proposed privatization projects that were submitted to the government before privatization. ${ }^{30}$ We use the number of privatization projects per se as an important IV since many SOEs attracted several privatization project proposals, reflecting the degree of investor interest and expected future performance of the firm. ${ }^{31}$ Moreover, for each privatized firm we use as IVs the pre-privatization data on registered (share) capital, net asset value, total number of shares, number of shares entering voucher privatization, number of shares allocated through voucher privatization, value of shares allocated through voucher privatization in voucher points, geographic and industry location of the firm, and the structure of share ownership among various domestic and foreign parties as proposed in the winning privatization project. The share ownership variables include the share that the government intended to keep for the short or long term. ${ }^{32}$ Finally, our set of IVs contains annual

\footnotetext{
${ }^{29}$ This approach is used in some studies, such as Frydman et al. (1999).

${ }^{30}$ Privatization of each enterprise was based on an officially accepted privatization project. The management of each enterprise had to submit a privatization proposal, but any domestic or foreign firm, institution or individual could present a competing privatization project. All proposals were to be considered on an equal footing by the privatization authorities, which worked with the investors to ensure that the final submitted proposals reflected at least in part government objectives in terms of ownership structure and other characteristics. Each project proposals had to contain recent economic and financial information about the enterprise and describe the proposed method of privatization, as well as the proposed organization of the privatized enterprise. See Kotrba and Svejnar (1994) for a description.

${ }^{31}$ In the case of larger firms, a number of proposals were submitted for privatizing a particular small asset that was not connected with the firm's production process (e.g., the firm's recreational facility in a national park). In order to avoid mixing these privatizations with those covering principal productive activities, we only consider projects aiming at privatization $10 \%$ or more of the enterprise's assets.

${ }^{32}$ Short-term government ownership reflects the expectation of the government of being able to sell appreciated shares shortly after privatization, while long-term government ownership indicates an expectation of slower appreciation of the value of the privatized firm and/or its strategic character in the economy. Parts of the shares retained by the government were also classified as intended for restitution or future sale through an intermediary.
} 
observations on the SOE's sales, profit, debt, and employment during the three consecutive years preceding privatization. The three-year panel permits us to capture the evolution of enterprise performance before privatization. For the sake of comparability across firms, we scale these indicators by the total number of shares. The summary statistics related to the instrumental variables are contained in Appendix Tables A3-A5.

We use the Hausman (1978) specification test for assessing endogeneity of the initial post-privatization ownership, comparing the results of first-difference OLS estimation with those from the first-difference IV method in which we treat ownership as potentially endogenous and instrument it by the IVs described above. The test is carried out by differencing the two sets of parameter estimates and standardizing the vector of differences by the difference in the covariance matrices of the two sets of estimates. The resulting quadratic form is asymptotically chi-squared with degrees of freedom equal to the number of parameters being tested. ${ }^{33}$ Results of the Hausman test confirm that 1996 ownership should be treated as endogenous. ${ }^{34}$

Unlike for 1996 ownership, the pre-privatization IVs are not adequate predictors of the 1996-99 changes in ownership. Moreover, we do not find other variables that can serve as reasonable instruments for this purpose. As a result, we control for possible endogeneity problems associated with changes in ownership in the 1996-99 period by including in equation (2) ownership group fixed effects $\delta_{j}$ for firms undergoing ownership changes. ${ }^{35}$ These $\delta_{j}$ effects may be interpreted as proxying unobserved performance characteristics of the acquired firms (i.e., new owners cherry picking winners or taking over losers) or reflecting the instantaneous (short-term) effects of new ownership on performance. In order to check the robustness of our results, we have also estimated models that, analogously to including $X_{i j l}$ as a regressor, control for $X_{i j \tau}$-- the performance achieved by the previous owner at the time $\tau$ when there is a change of ownership in 1996-99. This specification did not produce materially different results from those of equation (2).

\footnotetext{
${ }^{33}$ In practice, some diagonal elements of the covariance matrix are negative. As usual, we carry out the test only for parameters corresponding to the positive diagonal elements, with a corresponding correction to the degrees of freedom, using the generalized inverse matrix (procedure YINVO in TSP 4.5).

${ }^{34}$ We reject the null hypothesis of ownership being exogenous in regressions including all performance variables but profit/sales (significant on 7\% test level). However, in the case of profit/sales neither model shows a good fit of the data. This fact may to a large extent explain the non-rejection of the null hypothesis. ${ }^{35}$ Analogously to including $X_{i j 1}$ as a regressor, we have also estimated models controlling for $X_{i j \tau}$, the effect of performance achieved by the previous owner at the time of change of ownership $\tau$ on future performance. This specification did not produce materially different results from those of equation (2).
} 


\section{Empirical Results}

Our estimates are generated by the Huber (1967)--White (1982) procedure yielding heteroskedasticity-adjusted residuals in the presence of instrumental variables and we have also checked that the residuals are free from serial correlation.

\subsection{Instrumental Variable Equations (First Stage)}

In Appendix Tables A6 and A7 we report the estimated marginal effects from the first stage logit regressions for the probability that a firm has a given SLO or extent of ownership, respectively. The first stage regressions have a relatively good fit, with the scaled (pseudo) $\mathrm{R}^{2} \mathrm{~s}$ ranging from 0.11 to 0.52 . To verify the robustness of the logit results, we also ran OLS regressions in which we predicted the actual share of each ownership category and subsequently constructed predicted ownership dummy variables. Differences between the two sets of estimates are negligible.

The estimates in Tables A6 and A7 reflect a number of interesting and plausible patterns. The region of the firm is an important predictor for a number of categories of ownership, with foreign industrial (and majority and blocking minority foreign) firms for instance tending to acquire firms in Prague and its surroundings (Central Bohemia), as well as near the German and Austrian borders (Southern, Western and Northern Bohemia and Southern Moravia). Ownership proposed in the winning privatization project is also a strong predictor, with a 1 percent increase in the extent of proposed foreign ownership for example reducing the probability of eventual ownership by a domestic industrial company by about 1 percent. The number of privatization projects submitted for a given firm has a strong positive effect on the probability that the firm is owned by domestic industrial company, bank or investment fund, and that it has majority or legal minority domestic ownership. Finally, firm size, measured by the number of shares, has a positive effect on ownership by banks, foreign non-industrial owners and domestic majority owners, but a negative effect on foreign industrial ownership. Overall, the IVs have relatively strong and intuitively expected effects, most of them are strongly pre-determined through time and they pass the Sargan test of overidentifying restrictions. 


\subsection{The Effects of Ownership on Performance}

In Tables 4 and 5, we present the estimated coefficients of the instrumented equation (2) for the SLO and extent of ownership, respectively. ${ }^{36}$ The top panel of each table contains estimates of the permanent effect $\beta_{j}$ of the initial (1996) post-privatization ownership $P_{i j l}$, the second panel gives the estimates of the permanent effect $\theta_{j}$ of the subsequent ownership $P_{i j \tau}$ established after 1996, and the thirds panel presents the estimated instantaneous effect $\delta_{j}$ of the post-1996 change in ownership $\Delta P_{i j \tau}$.

In examining the results, we note the extent to which different types of ownership result in defensive restructuring (reducing labor cost and possibly also sales) versus strategic restructuring (increasing sales revenues, labor productivity and/or profits). We also highlight outcomes that are consistent with looting of the firm. Since the latter outcomes are inferred from the relative effects on sales, labor cost and profitability (e.g., increased sale and/or reduced labor costs not being accompanied by higher profits), these findings are also consistent with other phenomena such as changes in non-labor costs, and non-sales income.

The estimated coefficients in the two tables make it clear that the performance effects of privatization and different types of ownership are surprisingly limited and that many types of private ownership do not generate effects that are different from those of substantial state ownership. Moreover, the overall fit of these regressions suggests that ownership explains a very small part of total variation in the rate of change of corporate performance after privatization.

\section{Single Largest Owner}

As may be seen from the first panel of Table 4, the only initial post-privatization SLO that has a positive effect on sales is foreign industrial company. All five types of domestic non-state SLOs, as well as the foreign non-industrial SLO, register effects that are not statistically different from the effect of the state SLO. In terms of labor costs (employment), only firms with domestic industrial companies and investment funds as SLOs show a negative effect relative to the state. Finally, only firms with foreign industrial

\footnotetext{
${ }^{36}$ The corresponding OLS estimates are reported in Appendix Tables A8 and A9, respectively. In Tables 4 and 5, the constant reflects the 1996-97 rate of change in performance of firms that have state as a SLO and majority owner, respectively, were partially privatized outside of the voucher scheme, and operate in the miscellaneous ("other") category of the nineteen industries for which we control. The estimated coefficients on the various forms of ownership represent the average annual ownership effects relative to the effect of state SLO or majority ownership.
} 
companies as SLOs have a positive effect on profit/sales and no SLO type generates a significant effect on ROA. The post-privatization foreign industrial owners thus increase profitability by enhancing the rate of growth of sales, without having a differential effect from state firms on the rate of growth of labor cost (employment). Their domestic counterparts and investment fund SLOs reduce the rate of growth of labor cost, but do not display a corresponding positive effect on profit. The restructuring carried out by foreign industrial firms is of a strategic nature, while that performed by the domestic industrial company and investment fund SLOs is of a defensive type and is also consistent with the phenomenon of dissipation of profit (looting).

The permanent effects of the SLOs that come into existence after 1996 display a number of similarities to, but also more statistical significance than, the effects of immediate post-privatization ownerships. The basic pattern persists in that (a) most types of private owners do not show significant deviations from the sales, labor cost and profitability effects given by the base category of state SLOs, (b) foreign industrial firms raise sales and (c) domestic industrial and investment fund owners reduce labor cost. The new patterns are that firms acquired after 1996 by investment funds and portfolio companies experience a reduction in sales, foreign industrial SLOs increase not only sales but also labor costs and they no longer have a positive effect on profitability, bank SLOs have a positive effect on profit/sales and ROA, and non-industrial foreign SLOs have a negative effect on profit/sales. These results suggest that the more recent foreign industrial owners acquire firms to expand production but they no longer hold back the rate of growth of labor cost (employment), investment funds reduce the scale of operations, bank and portfolio company SLOs increase efficiency by reducing non-labor costs and/or increasing non-sales income, and domestic industrial and foreign non-industrial SLOs may suffer from looting (transfer pricing). ${ }^{37}$

Interestingly, there are only three instantaneous effects associated with the changes in ownership after 1996. Moreover, two of them (higher labor cost for firms acquired by investment funds and negative effect on ROA for firms acquired by banks) may represent a short term effect that is subsequently offset by an opposite permanent effect (second panel in the Table 4).

\footnotetext{
${ }^{37}$ In the case of banks, the permanent ROA effect in part offsets a negative instantaneous effect observed at the time of the shift to bank ownership (third panel in Table 4). The fact that the instantaneous effect is negative for ROA and not for profit/sales suggests that the banks acquire firms with (a) normal performance
} 
The effect of government control through the institution of a golden share is to raise the rate of increase of labor costs with no corresponding effect on the rate of change of sales or profitability. With the SLO specification of ownership, the government therefore appears to pursue a socially oriented goal of increasing employment and/or wages without a corresponding positive effect on sales or negative effect on profitability.

\section{Extent of Ownership}

The estimated effects of the extent of ownership by the three key ownership groups, reported in Table 5, complement the results with respect to the SLOs. Majority and minority post-privatization ownerships by most types of private owners do not generate effects that are statistically different from the base effect of majority state ownership. The notable exception is majority ownership by foreign companies which has a strong positive effect on the rate of change of sales, thus generating an effect that parallels that of foreign industrial SLOs. ${ }^{38}$ The difference is that majority foreign-owned firms, unlike foreign industrial SLOs, do not produce a positive effect on profitability. This difference may be brought about by the different composition of the majority and SLO foreign groups, rising non-labor costs or falling non-sale income in the majority foreign owned firms, or dissipation of profit by majority foreign owners through transfer pricing. Firms with majority and blocking minority domestic private ownership, like firms with domestic industrial company and investment fund SLOs in Table 4, are the only ones that significantly reduce labor costs (employment). Since no type of post-privatization ownership registers significant effects with respect to either indicator of profitability, the reduction in labor cost by concentrated domestic owners may be accompanied by increased non-labor cost or falling non-sales income, or looting.

Overall, the effects of initial post privatization ownership indicate that concentrated foreign ownership increases sales revenue, while highly as well as moderately concentrated domestic owners reduce labor cost (employment) relative to others. These asymmetric findings with respect to sales and labor cost effects of concentrated domestic and foreign owners are provocative because it has been widely presumed that both domestic and foreign private ownership, especially in highly concentrated forms, would lead to

in terms of profit/sales and increase this measure of profitability over time and (b) relatively large and unproductive assets, as measured by below average ROA, and raise the value of this indicator over time.

${ }^{38}$ There is also a positive effect of highly dispersed ownership. This group is comprised of a small number of firms, however, and there is an offsetting effect associated with subsequent ownership by this group. 
substantial strategic restructuring and increases in sales -- domestically and/or on the world markets.

The permanent effects of ownership changes that took place after 1996 show some similarities but also significant differences from the effects of initial post-privatization ownership. A post-1996 shift to majority foreign ownership has a positive effect on the rate of change of sales revenue that is not accompanied by an increase in labor cost or profitability. This suggests that foreign owners that acquire majority stakes in firms after privatization engage in productivity-enhancing strategic restructuring and either incur increased non-labor costs and/or falling non-sale revenue, or they siphon off profits. In contrast, shifts to blocking minority state and domestic ownership bring about negative effect on both sales and labor cost, indicating that these somewhat less concentrated owners react defensively by downsizing the newly acquired companies.

A switch to majority domestic ownership results in a positive permanent effect on both measures of profitability. Interestingly, positive permanent effects on ROA are also observed with shifts to blocking minority foreign and legal minority domestic ownerships. Moreover, the relatively rare shifts to legal minority state ownership also generate sizable positive effects on profit/sales.

As may be seen from Table 5, firms in which the state retains a golden share register a positive effect on sales, labor cost and ROA. These effects complement the estimates from the SLO specification and suggest that the state pursues an objective of increasing employment and output (revenue), while also inducing profit-oriented restructuring relative to assets. Since the state retains golden shares primarily in stateowned and domestic private firms (Table 2), the effect of a golden share moderates the tendency in some of these firms to reduce output (sales) and/or employment.

\section{Concluding Observations}

With the former Soviet bloc and many other developing countries having rapidly privatized their state-owned enterprises, and the populous economies of China, India and Vietnam being in the process of privatization, it is important to have a solid understanding of the effects of privatization and different forms of ownership on performance. While theory generates conflicting predictions, most surveys of the empirical literature suggest that a shift from state to private ownership tends to improve economic performance. However, much of the literature suffers from serious data problems and inadequate 
treatment of endogeneity (selection) of ownership, thus leaving the results in doubt. In this paper, we analyze this issue using rich panel data covering an entire population of firms that went through mass privatization in a model transition economy (Czech Republic), having the benefit of sizable variation in key variables during a large natural experiment and addressing carefully the principal data issues, including omitted variables bias, measurement error and endogeneity (selection) of ownership.

Overall, our econometric estimates present a much less sanguine picture than the generally accepted stylized facts, suggesting that the expectations and early findings of positive effects of privatization on corporate performance were premature. Contrary to many earlier studies, our results indicate that the performance effects of privatization and different types of ownership are on the whole surprisingly limited and that many types of private owners do not generate performance that is different from that of firms with state ownership. This lack of difference in performance is provocative because it has generally been assumed that various private owners would perform better than the state and the extent of inefficiency and looting of firms associated with various types of private ownership has been underestimated.

The key exceptions to the above result are concentrated foreign owners (industrial companies), which yield superior performance compared to all other types of owners in terms of growth of sales and in some specifications also profit (strategic restructuring), and concentrated domestic owners (industrial companies and investment funds), which reduce employment relative to others (defensive restructuring). These findings are consistent with the agency theory prediction that concentrated ownership results in superior corporate performance and they go against theories stressing the positive effects of managerial autonomy.

Apart from its effect as an owner, the state plays an interesting part by retaining control through a golden share in some firms. In particular, it increases employment and in one of the two specifications it also generates a positive effect on ROA and sales revenue. The state hence pursues both a social (employment generating) objective and corporate restructuring. Since our analysis covers the period of rising unemployment, the state appears as a more economically and socially beneficial agent than has been argued in some earlier studies (e.g., Djankov and Murrell, 2002, and Shleifer and Vishny, 1994). 


\section{References}

Allen, F. and D. Gale. 1995. "A welfare comparison of intermediaries in Germany and the US.” European Economic Review, 39(2): 179-209.

Angelucci, M., S. Estrin, J. Konings, and Z. Zólkiewski. 2002. "The Effect of Ownership and Competitive Pressure on Firm Performance in Transition Countries: Micro Evidence from Bulgaria, Romania and Poland," The William Davidson Institute Working Paper No. 434, Ann Arbor, MI.

Aghion, P., and W. Carlin. 1996. Restructuring Outcomes and the Evolution of Ownership Patterns in Central and Eastern Europe. Economics of Transition, 4(2), 371-88.

Aghion, P., and J. Tirole. 1997. "Formal and Real Authority in Organizations," Journal of Political Economy, 55: 1-27.

Ashenfelter, O., and Card, D. 1985. "Using the Longitudinal Structure of Earnings to Estimate the Effect of Training Programs". Review of Economics and Statistics 67(4), 648-60.

Barberis, N., M. Boycko, A. Shleifer and N. Tsukanova. 1996. "How Does Privatization Work? Evidence from the Russian Shops." Journal of Political Economy 104, 76490.

Barro, Robert J. and Sala-i-Martin, Xavier. 1995. Economic growth. Advanced Series in Economics. New York, London and Montreal: McGraw-Hill.

Bevan, Alan, Saul Estrin and Mark Schaffer. 1999. Determinants of Enterprise Performance during Transition. Centre for Economic Reform and Transformation (CERT) Working Paper 99/03.

Bilsen, V. and J. Konings. 1998. "Job Creation, Job Destruction, and Growth of Newly Established, Privatized, and State-Owned Enterprises in Transition Economies: Survey Evidence from Bulgaria, Hungary, and Romania," Journal of Comparative Economics, 26 (1998): 429-445

Blanchard, O. 1997. The Economics of Post-Communist Transition. Oxford: Oxford University Press.

Bolton, Patrick, and Ernst-Ludwig von-Thadden. 1998. "Blocks, Liquidity, and Corporate Control." Journal of Finance, 53(1), 1-25.

Boubakri, N. and J.C. Cosset. 1998. "The Financial and Operating Performance of Newly Privatized Firms: Evidence from Developing Countries," Journal of Finance, 53 (3) 1081-1110.

Burkart, M., D. Gromb and F. Panunzi, 2000. "Agency Conflict in Public and Negotiated Transfer of Corporate Control." Journal of Finance, 55 (2) 647-677.

Carlin, W., S. Fries, M.E. Schaffer, and P. Seabright. 2001. "Competition and Enterprise Performance in Transition Economies: Evidence from a Cross-country Survey," CEPR Discussion Paper DP2840, London.

Caves, D.W. and L. Christensen. 1980. "The Relative Efficiency of Public and Private Firms in a Competitive Environment: The Case of Canadian Railroads," Journal of Political Economy, 88 (5), 958-76.

Claessens, S. 1997. "Corporate Governance and Equity Prices:Evidence from the Czech and Slovak Republics," Journal of Finance, 52 (4) 1641-1658.

Claessens, S. and S. Djankov. 1999. "Ownership Concentration and Corporate Performance in the Czech Republic." Journal of Comparative Economics 27 498513.

Coffee, J. 1996. Institutional Investors in Transitional Economies: Lessons from the Czech Experience. In: Frydman, R., Gray, C., and Rapaczynski, A. (eds.): Corporate 
governance in Central Europe and Russia. Vol. 1. Banks, funds, and foreign investors. Budapest, Central European University Press 1996, s. 111-86.

Cornelli, F., Portes R., and Schaffer M. E. 1996. The Capital Structure of Firms in Central and Eastern Europe. CEPR Discussion Paper No. 1392.

DeWenter, Kathryn L. and Malatesta, Paul H., 2001, State-Owned and Privately Owned Firms: An Empirical Analysis of Profitability, Leverage, and Labor Intensity American Economic Review, 91(1): 320-34

Demsetz, Heinz and Karl Lehn. 1985. The Structure of Corporate-Ownership - Causes and Consequences. Journal of Political Economy 93: (6) 1155-1177.

Djankov, S. and Murrell, P. 2002. "Enterprise Restructuring in Transition: A Quantitative Survey." Journal of Economic Literature, XL (3) 739-792.

D'Souza, J. and W. Megginson. 1999. "The Financial and Operating Performance of Privatized Firms during the 1990s," Journal of Finance, 54 (4) 1397-1438.

Filer, R. K. and J. Hanousek. 2002. "Data Watch: Research Data from Transition Economies." Journal of Economic Perspectives 16, 1, 225-240.

Frydman, R., C.W. Gray, M. Hessel and A. Rapaczynski. 1999. "When does Privatization Work? The Impact of Private Ownership on Corporate Performance in Transition Economies." Quarterly Journal of Economics 114: 1153-91.

Frydman, R., M. Hessel and A. Rapaczynski. 2000. Why Ownership Matters? Entrepreneurship and the Restructuring of Enterprises in Central Europe. C.V. Starr Center for Applied Economics Working Paper, NYU, New York.

Grosfeld, I. and J.F. Nivet. 1997. "Firm's Heterogeneity in Transition: Evidence From a Polish Panel Data Set," William Davidson Institute Working Paper No.47, 1997.

Grosfeld, I. and Roland, G. 1997. "Defensive and Strategic Restructuring in Central European Enterprises." Journal of Transforming Economies and Societies, 3(4): 21-46.

Grosfeld, I. and T. Tressel. 2001. "Competition and Corporate Governance: Substitutes or Complements? Evidence from the Warsaw Stock Exchange," William Davidson Institute WP No. 369.

Gupta, N., J. C. Ham, and J. Svejnar. 2000. Priorities and Sequencing in Privatization: Theory and Evidence from the Czech Republic. William Davidson Institute WP No. 323.

Hausman, J. 1978. "Specification Tests in Econometrics.” Econometrica 46 (6):1251-1271. Heckman, J. 1979. "Sample selection bias as a specification error." Econometrica 47: 153161

Heckman, J., and Hotz, V. 1989. "Choosing among Alternative Nonexperimental Methods for Estimating the Impact of Social Programs: The Case of Manpower Training." Journal of the American Statistical Association 84(408), 862-74.

Holmström, B., and J. Tirole. 1983. "Market liquidity and performance monitoring," Journal of Political Economy, 101: 678-709.

Huber, P. J. 1967. The behavior of maximum likelihood estimates under nonstandard conditions. Proceedings of the Fifth Berkeley Symposium on Mathematical Statistics and Probability, 221-223. Berkeley, CA: University of California Press.

Kočenda, E. 1999. Residual State Property in the Czech Republic. Eastern European Economics, 37, 5, 6-35.

Kočenda, E., and Valachy, J. 2002. Firm Ownership Structures: Dynamic Development. Prague Economic Papers, 11, 3, 255-268.

Kotrba, J.: Privatization Process in the Czech Republic: Players and Winners, pp. 159-198. In Svejnar, J., The Czech Republic and economic transition in Eastern Europe. San Diego; London and Toronto: Harcourt Brace, Academic Press, 1995. 
Kotrba, J. and J. Svejnar. 1994. Rapid and Multifaceted Privatization: Experience of the Czech and Slovak Republics. Nomisma/Most, 147-185.

Lízal, L. and E. Kočenda. 2001. State of Corruption in Transition: The Case of the Czech Republic. Emerging Markets Review, 2, 2, 138-160.

Lízal, L. and J. Svejnar. 2002. "Investment, Credit Rationing, and the Soft Budget Constraint: Evidence from Czech Panel Data," The Review of Economics and Statistics, 84(2), 353-370.

Megginson, W.L. and Netter J.R. 2001. "From state to market: A survey of empirical studies on privatization", Journal of Economic Literature 39: (2) 321-389, June.

Munich, D., J. Svejnar and K. Terrell. 2002. Returns to Human Capital under the Communist Wage Grid and During the Transition to a Market Economy. The William Davidson Institute Working Paper No. 272, forthcoming in The Review of Economics and Statistics, February 2005.

Pohl, G., R. Anderson, S. Claessens, and S. Djankov. 1997. Privatization and Restructuring in Central and Eastern Europe: Evidence and Policy Options. World Bank Technical Paper No. 368.

Roland, G. Transition and Economics: Politics, Markets and Firms. Cambridge, MA: MIT Press, 2000.

Sachs, Jeffrey, Clifford Zinnes and Yair Eilat. 2000. The Gains from Privatization in Transition Economies: Is Change of Ownership Enough? CAER II Discussion Paper 63, Harvard Institute for International Development, Cambridge, MA.

Shirley, Mary and Patrick Walsh. 2000. Public versus Private Ownership: The Current State of the Debate. The World Bank, Washington, DC, 2000.

Shleifer, A., and Vishny, R. 1994. "Politicians and Firms," Quarterly Journal of Economics, CIX(4) 995-1023, November.

Shleifer, A., and Vishny, R. 1997. "A Survey of Corporate Governance," Journal of Finance, 52(2): 737-783.

Smith, S., B. Cin, and M. Vodopivec. 1997. Privatization Incidence, ownership Forms, and Firm Performance: Evidence from Slovenia. Journal of Comparative Economics, 25, 158-179.

Svejnar, J. and M. Singer. 1994. Using Vouchers to Privatize an Economy: The Czech and Slovak Case. Economics of Transition 2, 43-64.

Temple, Jonathan. 1999. The New Growth Evidence. Journal of Economic Literature, 37(1): 112-56.

White, H. 1982. Maximum likelihood estimation of misspecified models. Econometrica 50:1-25. 
Table 1

Summary Statistics of Performance Indicators: 1996-1999

\begin{tabular}{lcccccc}
\hline \hline & Mean & Std. Dev. & Min & Max & No. Firms & No.Obs. \\
\hline ROA & 0.001 & 0.098 & -0.393 & 0.387 & 1540 & 2905 \\
& & & & & & \\
Profit / Sales & -0.267 & 0.982 & -2.995 & 2.985 & 1289 & 2164 \\
Sales & 0.009 & 0.426 & -1.000 & 2.820 & 1371 & 2592 \\
Labor Costs & 0.010 & 0.364 & -1.000 & 2.842 & 1539 & 2949 \\
\hline \hline
\end{tabular}

The ratio of the number of observations to number of firms varies due to an unbalanced nature of the panel.

ROA is defined as a ratio of change in profits between two consecutive periods to total assets at the beginning period. Formally: [(Profit(t)-Profit(t-1))/Total Assets(t1)]. 
Table 2

Ownership Extent and Categories: Summary Statistics

Panel A: Type of Ownership by Single Largest Owner (SLO)

\begin{tabular}{|c|c|c|c|c|c|c|c|}
\hline \multirow[b]{2}{*}{$\begin{array}{l}\text { Type of single } \\
\text { largest owner } \\
\text { (SLO) }\end{array}$} & \multirow[b]{2}{*}{$\begin{array}{l}\text { Num. } \\
\text { of obs. }\end{array}$} & \multirow[b]{2}{*}{$\begin{array}{l}\text { Mean } \\
\text { size of } \\
\text { stake } \\
(\%)\end{array}$} & \multicolumn{5}{|c|}{ Number of Observations } \\
\hline & & & $\begin{array}{l}\text { Majority } \\
\text { held by } \\
\text { SLO }\end{array}$ & $\begin{array}{l}\text { Blocking } \\
\text { Minority } \\
\text { held by } \\
\text { SLO }\end{array}$ & $\begin{array}{l}\text { Legal Minority } \\
\text { (Moderately } \\
\text { Dispersed } \\
\text { Ownership) }\end{array}$ & $\begin{array}{c}\text { Other } \\
\text { (Highly } \\
\text { Dispersed } \\
\text { Ownership) }\end{array}$ & $\begin{array}{l}\text { Golden } \\
\text { Share } \\
\text { held by } \\
\text { State }\end{array}$ \\
\hline \multicolumn{8}{|c|}{ Domestic Ownership } \\
\hline Industrial Co. & 1244 & 48.83 & 547 & 412 & 272 & 13 & 42 \\
\hline Bank & 33 & 46.42 & 11 & 14 & 7 & 1 & 1 \\
\hline Invest. Fund & 423 & 37.61 & 96 & 119 & 205 & 3 & 19 \\
\hline Individual & 335 & 38.92 & 82 & 99 & 150 & 4 & 13 \\
\hline Portfolio Co. & 80 & 45.06 & 22 & 35 & 22 & 1 & 5 \\
\hline State & 174 & 43.18 & 49 & 63 & 58 & 4 & 66 \\
\hline \multicolumn{8}{|c|}{ Foreign Ownership } \\
\hline Industrial Co. & 236 & 58.81 & 139 & 60 & 30 & 7 & 6 \\
\hline Others & 67 & 51.23 & 26 & 26 & 15 & 0 & 3 \\
\hline Total & 2592 & 46.16 & 972 & 828 & 759 & 33 & 155 \\
\hline
\end{tabular}

Panel B: Ownership Extent

\begin{tabular}{lccccccc}
\hline \hline & & \multicolumn{5}{c}{ Number of observations } \\
\cline { 5 - 8 } $\begin{array}{l}\text { Type of } \\
\text { aggregate } \\
\text { ownership }\end{array}$ & $\begin{array}{c}\text { Num. } \\
\text { of obs. }\end{array}$ & $\begin{array}{c}\text { Mean } \\
\text { size of } \\
\text { stake } \\
(\%)\end{array}$ & Majority & $\begin{array}{c}\text { Blocking } \\
\text { Minority }\end{array}$ & $\begin{array}{c}\text { Legal Minority } \\
\text { (Moderately } \\
\text { Dispersed } \\
\text { Ownership) }\end{array}$ & $\begin{array}{c}\text { Other } \\
\text { (Highly } \\
\text { Dispersed } \\
\text { Ownership) }\end{array}$ & $\begin{array}{c}\text { Golden } \\
\text { Share } \\
\text { held by } \\
\text { State }\end{array}$ \\
\hline Domestic & 2115 & 44.84 & 758 & 679 & 656 & 22 & 80 \\
Foreign & 303 & 57.14 & 165 & 86 & 45 & 7 & 9 \\
State & 174 & 43.18 & 49 & 63 & 58 & 4 & 66 \\
\hline Total & 2592 & 46.16 & 972 & 828 & 759 & 33 & 155 \\
\hline \hline
\end{tabular}

Note: This table contains basic ownership statistics associated with the performance variable of sales. Statistics for other performance indicators are similar. Ownership concentration categories include majority (more than $50 \%$ of shares), blocking minority (from more than 33 to $50 \%$ of shares), legal minority (at least $10 \%$ but not more than $33 \%$ of shares), and other (less than $10 \%$ of shares). All ownership categories are mutually exclusive. The golden share is an additional measure that is not associated with any particular extent of ownership. 
Table 3

Movement of Firms across Ownership Categories: 1996-1999

Panel A: Type of Ownership by the Single Largest Owner (SLO)

\begin{tabular}{|c|c|c|c|c|c|c|c|c|c|}
\hline 1996 & $\begin{array}{l}\text { Domestic } \\
\text { Industrial } \\
\text { Co. }\end{array}$ & $\begin{array}{l}\text { Domestic } \\
\text { Bank }\end{array}$ & $\begin{array}{l}\text { Domestic } \\
\text { Investme } \\
\text { nt Fund }\end{array}$ & $\begin{array}{l}\text { Domestic } \\
\text { Individua } \\
\text { l }\end{array}$ & $\begin{array}{l}\text { Domestic } \\
\text { Portfolio } \\
\text { Co. }\end{array}$ & State & $\begin{array}{l}\text { Foreign } \\
\text { Industrial } \\
\text { Co. }\end{array}$ & $\begin{array}{l}\text { Foreign } \\
\text { Other }\end{array}$ & Total \\
\hline Domestic Industrial Co. & $69 \%$ & $1 \%$ & $11 \%$ & $10 \%$ & $2 \%$ & $1 \%$ & $6 \%$ & $1 \%$ & $100 \%$ \\
\hline Domestic Bank & $47 \%$ & $5 \%$ & $25 \%$ & $8 \%$ & $1 \%$ & $1 \%$ & $12 \%$ & $2 \%$ & $100 \%$ \\
\hline Domestic Investment Fund & $50 \%$ & $4 \%$ & $28 \%$ & $9 \%$ & $2 \%$ & $2 \%$ & $4 \%$ & $1 \%$ & $100 \%$ \\
\hline Domestic Individual & $39 \%$ & $1 \%$ & $9 \%$ & $43 \%$ & $1 \%$ & $1 \%$ & $6 \%$ & $1 \%$ & $100 \%$ \\
\hline Domestic Portfolio Co. & $56 \%$ & $2 \%$ & $18 \%$ & $14 \%$ & $2 \%$ & $2 \%$ & $5 \%$ & $1 \%$ & $100 \%$ \\
\hline State & $47 \%$ & $1 \%$ & $8 \%$ & $9 \%$ & $1 \%$ & $26 \%$ & $7 \%$ & $1 \%$ & $100 \%$ \\
\hline Foreign Industrial Co. & $15 \%$ & $0 \%$ & $1 \%$ & $3 \%$ & $1 \%$ & $0 \%$ & $75 \%$ & $5 \%$ & $100 \%$ \\
\hline Foreign Other & $35 \%$ & $1 \%$ & $8 \%$ & $15 \%$ & $1 \%$ & $0 \%$ & $33 \%$ & $8 \%$ & $100 \%$ \\
\hline
\end{tabular}


Panel B: Extent of State, Private Domestic and Foreign Ownership

\begin{tabular}{|c|c|c|c|c|c|c|c|c|c|c|c|}
\hline$x$ & $\begin{array}{c}\text { Majority } \\
\text { State }\end{array}$ & $\begin{array}{l}\text { Majority } \\
\text { Domestic }\end{array}$ & $\begin{array}{l}\text { Majority } \\
\text { Foreign }\end{array}$ & $\begin{array}{c}\text { Blocking } \\
\text { Minority } \\
\text { State }\end{array}$ & $\begin{array}{l}\text { Blocking } \\
\text { Minority } \\
\text { Domestic }\end{array}$ & $\begin{array}{c}\text { Blocking } \\
\text { Minority } \\
\text { Foreign }\end{array}$ & $\begin{array}{l}\text { Legal } \\
\text { Minority } \\
\text { State }\end{array}$ & $\begin{array}{c}\text { Legal } \\
\text { Minority } \\
\text { Domestic }\end{array}$ & $\begin{array}{l}\text { Legal } \\
\text { Minority } \\
\text { Foreign }\end{array}$ & $\begin{array}{c}\text { Other } \\
\text { than } \\
\text { Majority } \\
\text { or } \\
\text { Minority }\end{array}$ & Total \\
\hline Majority State & $46 \%$ & $29 \%$ & $5 \%$ & $2 \%$ & $11 \%$ & $4 \%$ & $0 \%$ & $2 \%$ & $0 \%$ & $0 \%$ & $100 \%$ \\
\hline Majority Domestic & $0 \%$ & $68 \%$ & $6 \%$ & $0 \%$ & $19 \%$ & $1 \%$ & $0 \%$ & $4 \%$ & $1 \%$ & $0 \%$ & $100 \%$ \\
\hline Majority Foreign & $0 \%$ & $13 \%$ & $73 \%$ & $0 \%$ & $4 \%$ & $9 \%$ & $0 \%$ & $1 \%$ & $1 \%$ & $0 \%$ & $100 \%$ \\
\hline $\begin{array}{l}\text { Blocking Minority State } \\
\text { Blocking Minority }\end{array}$ & $1 \%$ & $21 \%$ & $5 \%$ & $15 \%$ & $34 \%$ & $3 \%$ & $2 \%$ & $9 \%$ & $3 \%$ & $6 \%$ & $100 \%$ \\
\hline Domestic & $0 \%$ & $41 \%$ & $3 \%$ & $1 \%$ & $37 \%$ & $3 \%$ & $1 \%$ & $12 \%$ & $1 \%$ & $0 \%$ & $100 \%$ \\
\hline Blocking Minority Foreign & $0 \%$ & $21 \%$ & $19 \%$ & $0 \%$ & $21 \%$ & $35 \%$ & $0 \%$ & $2 \%$ & $2 \%$ & $0 \%$ & $100 \%$ \\
\hline Legal Minority State & $1 \%$ & $24 \%$ & $2 \%$ & $1 \%$ & $27 \%$ & $2 \%$ & $24 \%$ & $18 \%$ & $1 \%$ & $1 \%$ & $100 \%$ \\
\hline Legal Minority Domestic & $0 \%$ & $28 \%$ & $2 \%$ & $1 \%$ & $34 \%$ & $2 \%$ & $1 \%$ & $30 \%$ & $1 \%$ & $0 \%$ & $100 \%$ \\
\hline Legal Minority Foreign & $0 \%$ & $13 \%$ & $18 \%$ & $0 \%$ & $17 \%$ & $15 \%$ & $0 \%$ & $14 \%$ & $22 \%$ & $0 \%$ & $100 \%$ \\
\hline $\begin{array}{l}\text { Other than Majority or } \\
\text { Minority }\end{array}$ & $0 \%$ & $20 \%$ & $5 \%$ & $0 \%$ & $19 \%$ & $4 \%$ & $3 \%$ & $28 \%$ & $3 \%$ & $17 \%$ & $100 \%$ \\
\hline
\end{tabular}




\section{Table 4}

Effect of the Single Largest Owner (SLO) Type on Performance

Instrumented estimates (Standard errors in parentheses)

\begin{tabular}{|c|c|c|c|c|c|c|c|}
\hline & Sales & & $\begin{array}{r}\text { Labor } \\
\text { Cost }\end{array}$ & & $\begin{array}{c}\text { Profit } \\
\text { / Sales }\end{array}$ & & ROA \\
\hline State (Constant) & $\begin{array}{r}- \\
0.141 \\
(0.076) \\
\end{array}$ & 10 & $\begin{array}{r}0.034 \\
(0.053) \\
\end{array}$ & & $\begin{array}{r}-0.197 \\
(0.141) \\
\end{array}$ & & $\begin{array}{r}0.004 \\
(0.012) \\
\end{array}$ \\
\hline \multicolumn{8}{|c|}{ Initial Ownership Size $\left(P_{i j 1}\right)$ - Permanent Effect $(\beta j)$} \\
\hline \multicolumn{8}{|l|}{ Domestic Ownership } \\
\hline & - & & - & & & & - \\
\hline \multirow[t]{2}{*}{ Industrial Co. } & 0.027 & & 0.063 & 1 & 0.015 & & 0.002 \\
\hline & $(0.029)$ & & $(0.023)$ & & $(0.078)$ & & $(0.006)$ \\
\hline \multirow[t]{3}{*}{ Bank } & 0.025 & & 0.043 & & 0.005 & & 0.015 \\
\hline & $(0.065)$ & & $(0.055)$ & & $(0.154)$ & & $(0.014)$ \\
\hline & & & - & & & & - \\
\hline \multirow[t]{2}{*}{ Invest. Fund } & 0.015 & & 0.071 & 1 & -0.080 & & 0.006 \\
\hline & $(0.033)$ & & $(0.026)$ & & $(0.088)$ & & $(0.007)$ \\
\hline \multirow{3}{*}{ Individual } & 0.022 & & $0027^{-}$ & & -0081 & & 0001 \\
\hline & $\begin{array}{l}0.022 \\
(0.037)\end{array}$ & & $\begin{array}{l}0.027 \\
(0.031)\end{array}$ & & $\begin{array}{r}-0.081 \\
(0.095)\end{array}$ & & $(0.008)$ \\
\hline & & & 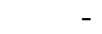 & & & & - \\
\hline \multirow[t]{2}{*}{ Portfolio Co. } & 0.042 & & 0.012 & & -0.098 & & 0.005 \\
\hline & $(0.068)$ & & $(0.051)$ & & $(0.134)$ & & $(0.012)$ \\
\hline \multicolumn{8}{|l|}{ Foreign Ownership } \\
\hline \multirow[t]{3}{*}{ Industrial Co. } & 0.107 & 1 & 0.026 & & 0.180 & 10 & 0.013 \\
\hline & $(0.042)$ & & $(0.031)$ & & $(0.111)$ & & $(0.009)$ \\
\hline & & & - & & & & - \\
\hline \multirow[t]{2}{*}{ Others } & 0.003 & & 0.055 & & -0.221 & & 0.006 \\
\hline & $(0.097)$ & & $(0.073)$ & & $(0.192)$ & & $(0.015)$ \\
\hline
\end{tabular}

\section{Subsequent Ownership Size $\left(P_{i j \tau}\right)$ - Permanent Effect $(\theta j)$}

Domestic Ownership

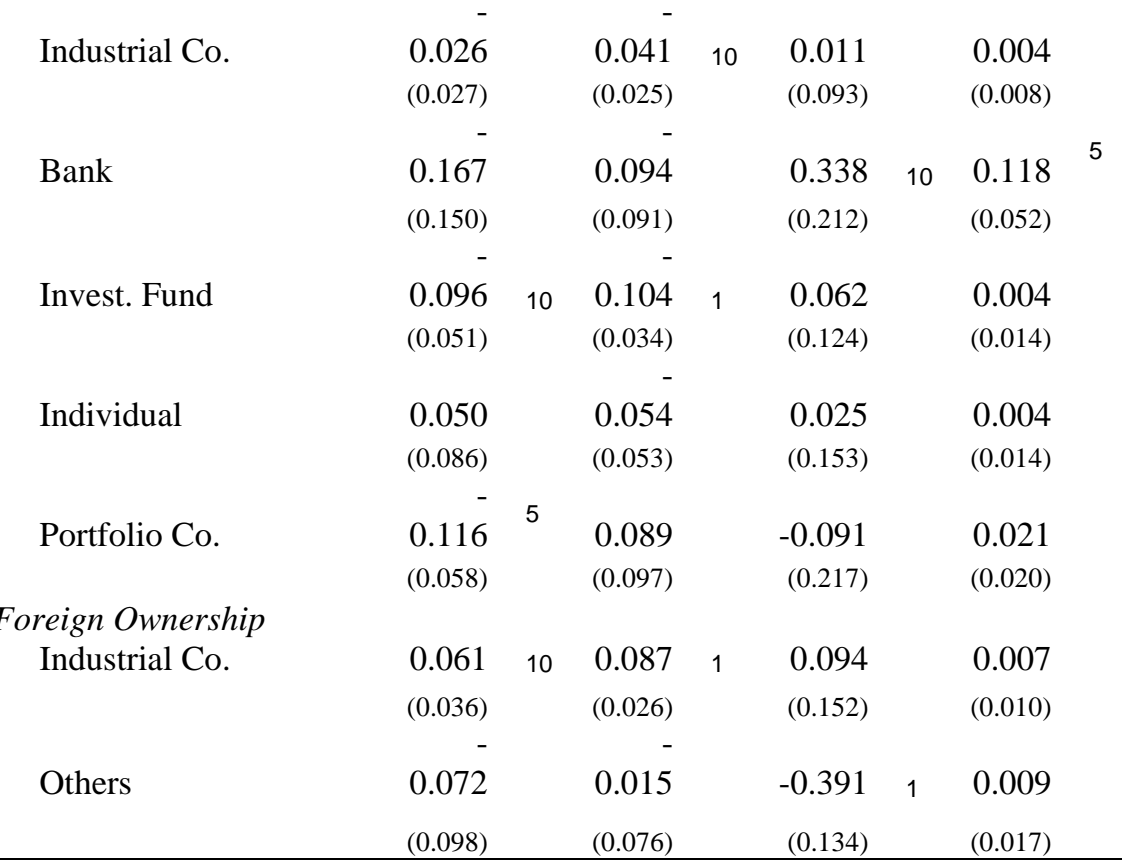


Ownership Change ( $\left.\Delta P_{i j \tau}\right)$ - Instantaneous Effect $(\delta j)$

Domestic Ownership

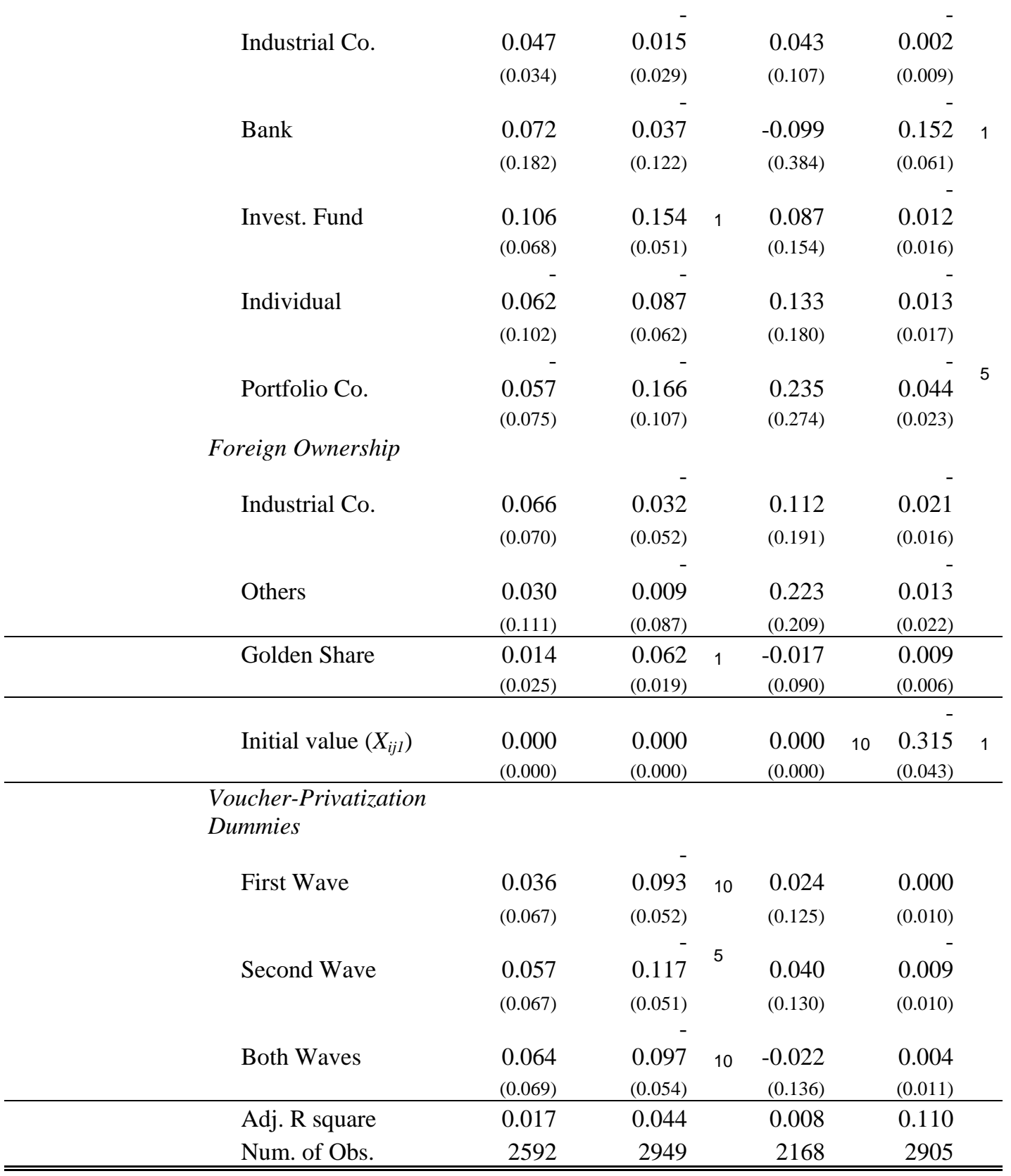

Note: The dependent variables are the rate of change of sales revenue, labor cost, and profit/sales, and the change in ROA, respectively. Numbers in parentheses are standard errors. Number 1, 5 and 10 denote significance at 1\%, 5\% and 10\% level, two-tail test, respectively. Industry, privatization, and year dummies are included. 
Table 5

Effect of Ownership Extent on Performance

Instrumented Estimates (Standard errors in parentheses)

\begin{tabular}{|c|c|c|c|c|c|}
\hline & Sales & & $\begin{array}{r}\text { Labor } \\
\text { Cost }\end{array}$ & $\begin{array}{r}\text { Profit / } \\
\text { Sales }\end{array}$ & ROA \\
\hline Majority State (Constant) & $\begin{array}{r}-0.175 \\
(0.103)\end{array}$ & 10 & $\begin{array}{l}0.026 \\
(0.054)\end{array}$ & $\begin{array}{r}-0.192 \\
(0.178)\end{array}$ & $\begin{array}{l}0.005 \\
(0.015)\end{array}$ \\
\hline
\end{tabular}

Initial Ownership Size $\left(P_{i j}\right)$ - Permanent Effect $(\beta j)$

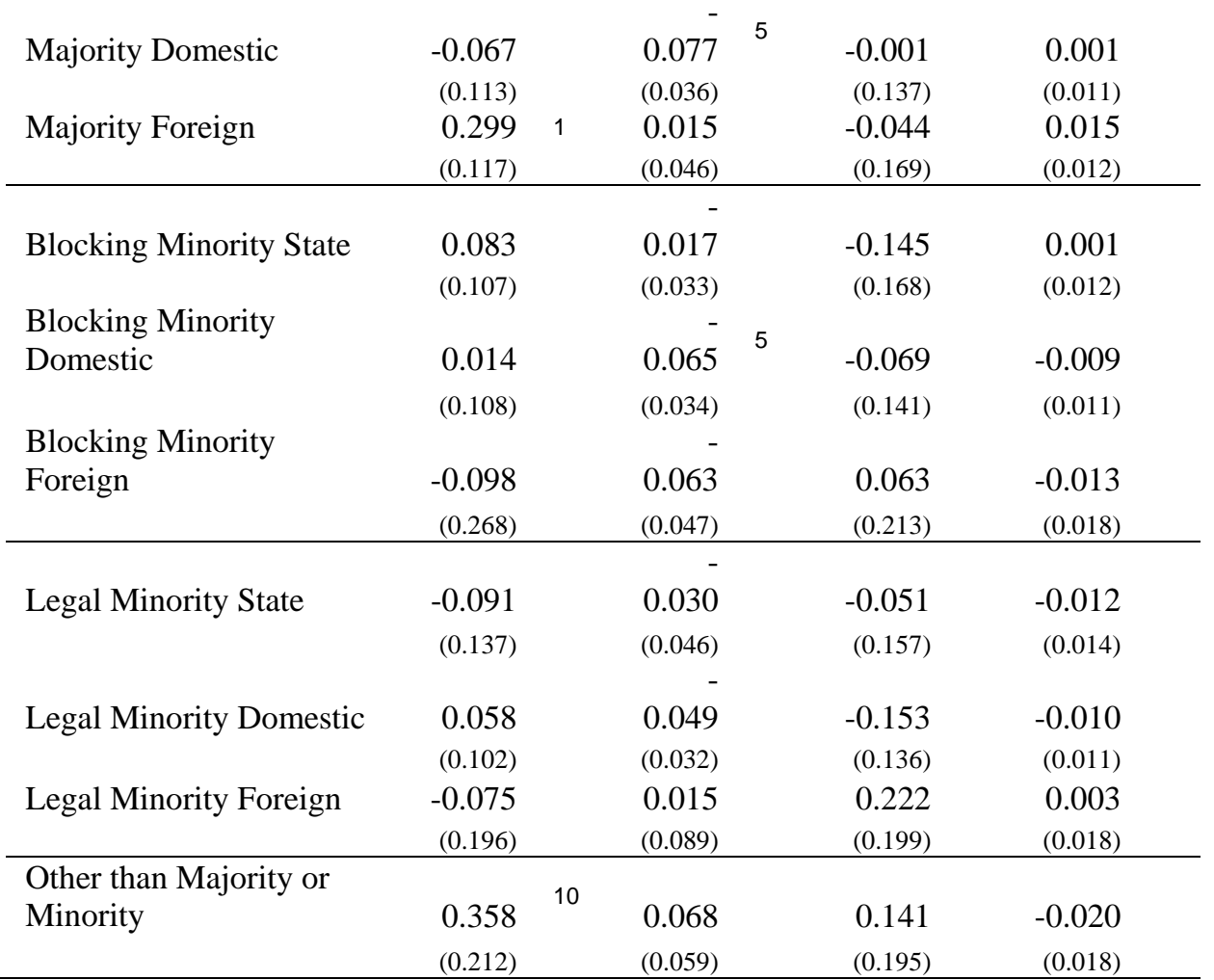

Subsequent Ownership Size $\left(P_{i j}\right)$ - Permanent Effect $(\theta j)$

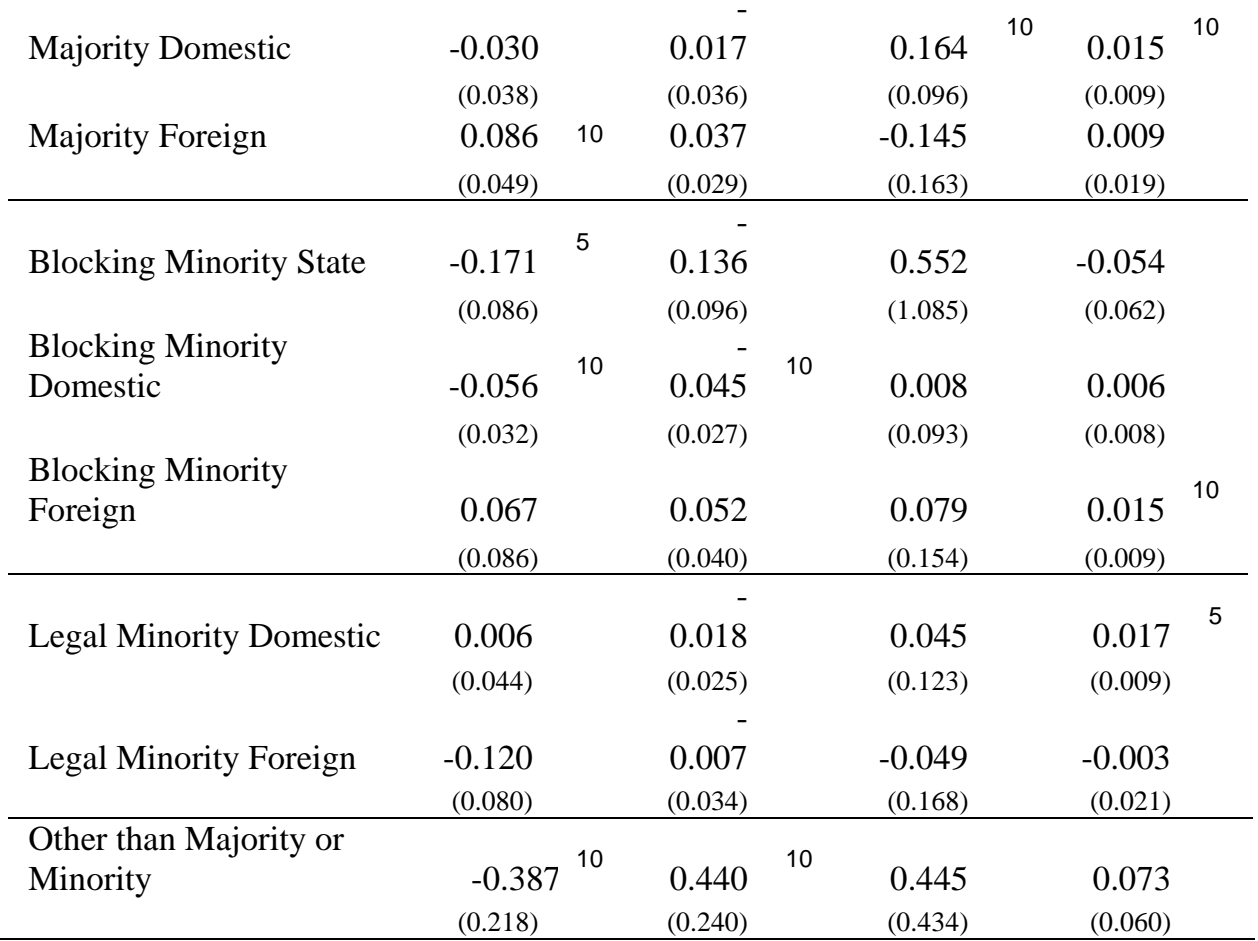


Ownership Change $\left(\Delta P_{i j \tau}\right)$ - Instantaneous Effect $(\delta j)$

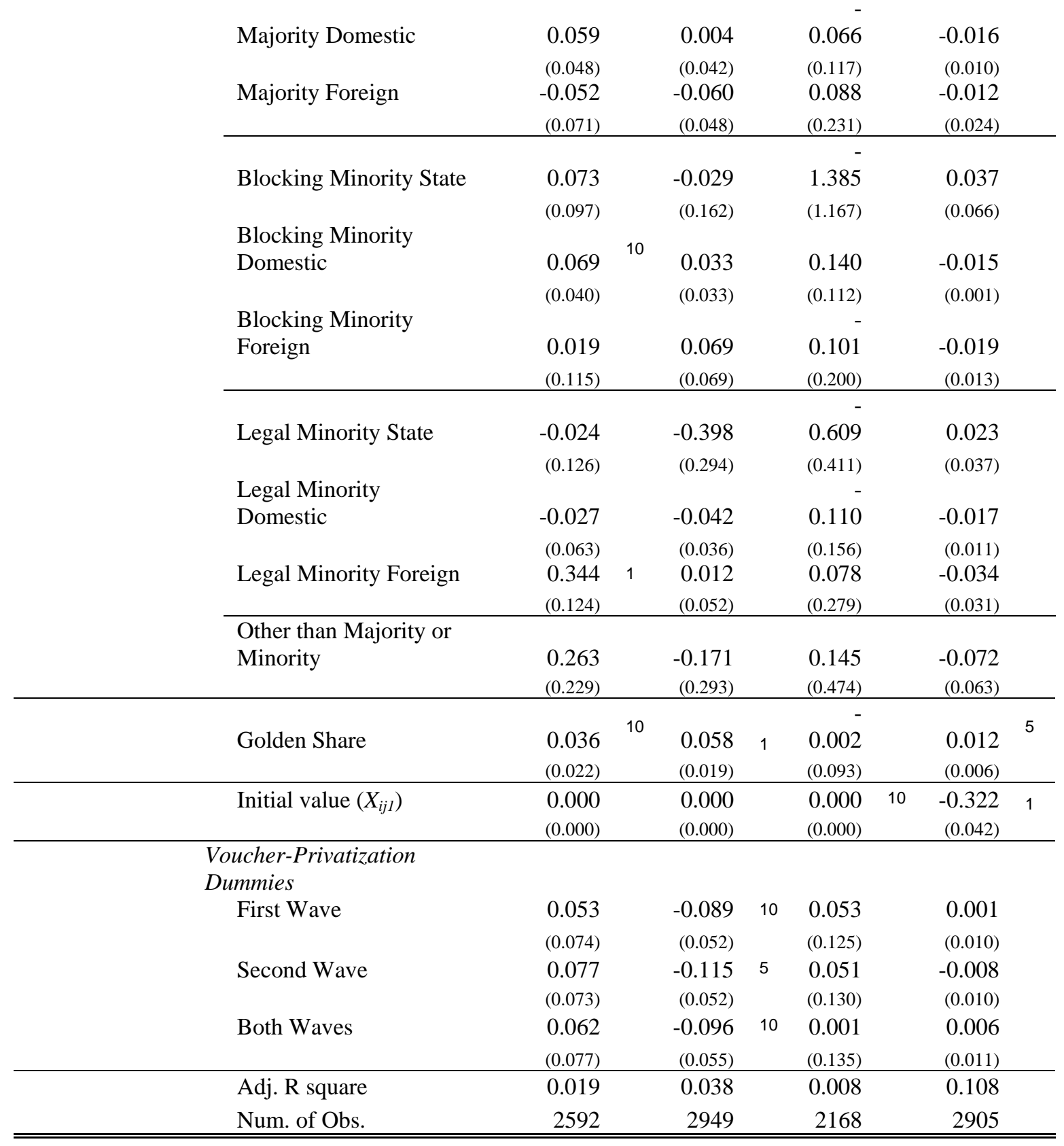

Note: The dependent variables are the rate of change of sales revenue, labor cost, and profit/sales, and the change in ROA, respectively. Numbers in parentheses are standard errors. Number 1, 5 and 10 denote significance at 1\%, 5\% and 10\% level, two-tail test, respectively. Industry, privatization, and year dummies are included. 
Table A1

Summary Statistics of Performance Indicators by Ownership Type: 1996-1999

\begin{tabular}{|c|c|c|c|c|c|c|c|}
\hline & & Mean & Std. Dev. & Min & Max & $\begin{array}{l}\text { Num. } \\
\text { Firms }\end{array}$ & $\begin{array}{c}\text { Num. } \\
\text { Obs }\end{array}$ \\
\hline \multicolumn{8}{|c|}{ Domestic Ownership } \\
\hline \multirow[t]{4}{*}{ Industrial Co. } & ROA & 0.002 & 0.100 & -0.393 & 0.386 & 852 & 1389 \\
\hline & Profit / Sales & -0.278 & 1.013 & -2.921 & 2.985 & 619 & 911 \\
\hline & Sales & -0.009 & 0.418 & -1.000 & 2.431 & 766 & 1244 \\
\hline & Labor Costs & -0.014 & 0.353 & -1.000 & 2.732 & 860 & 1410 \\
\hline \multirow{4}{*}{ Bank } & ROA & 0.008 & 0.121 & -0.377 & 0.373 & 40 & 45 \\
\hline & & -0.141 & 0.907 & -2.200 & 2.329 & 38 & 48 \\
\hline & Sales & 0.101 & 0.720 & -1.000 & 2.820 & 29 & 33 \\
\hline & Labor Costs & 0.083 & 0.453 & -0.782 & 1.876 & 39 & 43 \\
\hline \multirow{4}{*}{ Invest. Fund } & $\mathrm{ROA}$ & 0.006 & 0.109 & -0.369 & 0.387 & 332 & 474 \\
\hline & Profit / Sales & -0.327 & 1.030 & -2.995 & 2.954 & 280 & 397 \\
\hline & Sales & 0.016 & 0.444 & -1.000 & 2.726 & 297 & 423 \\
\hline & Labor Costs & 0.024 & 0.401 & -1.000 & 2.842 & 338 & 488 \\
\hline \multirow[t]{4}{*}{ Individual } & ROA & -0.001 & 0.102 & -0.385 & 0.387 & 258 & 380 \\
\hline & Profit / Sales & -0.308 & 0.992 & -2.987 & 2.674 & 187 & 259 \\
\hline & Sales & 0.016 & 0.522 & -1.000 & 2.691 & 224 & 335 \\
\hline & Labor Costs & -0.015 & 0.398 & -1.000 & 2.248 & 252 & 379 \\
\hline \multirow[t]{4}{*}{ Portfolio Co. } & ROA & -0.017 & 0.105 & -0.349 & 0.367 & 88 & 98 \\
\hline & Profit / Sales & -0.289 & 1.111 & -2.970 & 2.866 & 79 & 89 \\
\hline & Sales & -0.134 & 0.365 & -1.000 & 0.987 & 72 & 80 \\
\hline & Labor Costs & -0.008 & 0.496 & -1.000 & 2.750 & 88 & 100 \\
\hline \multirow[t]{4}{*}{ State } & ROA & -0.006 & 0.052 & -0.250 & 0.164 & 125 & 178 \\
\hline & Profit / Sales & -0.177 & 0.827 & -2.947 & 2.621 & 192 & 250 \\
\hline & Sales & 0.026 & 0.217 & -0.994 & 1.325 & 122 & 174 \\
\hline & Labor Costs & 0.081 & 0.238 & -0.989 & 2.219 & 128 & 183 \\
\hline \multicolumn{8}{|c|}{ Foreign Ownership } \\
\hline \multirow[t]{4}{*}{ Industrial Co. } & ROA & -0.001 & 0.077 & -0.298 & 0.235 & 154 & 259 \\
\hline & Profit / Sales & -0.129 & 0.871 & -2.967 & 2.744 & 109 & 173 \\
\hline & Sales & 0.105 & 0.380 & -1.000 & 2.795 & 140 & 236 \\
\hline & Labor Costs & 0.091 & 0.284 & -1.000 & 1.643 & 157 & 265 \\
\hline \multirow[t]{4}{*}{ Others } & ROA & -0.006 & 0.094 & -0.368 & 0.257 & 68 & 82 \\
\hline & Profit / Sales & -0.413 & 0.757 & -2.552 & 1.705 & 41 & 48 \\
\hline & Sales & -0.004 & 0.290 & -0.902 & 0.868 & 57 & 67 \\
\hline & Labor Costs & 0.033 & 0.333 & -0.800 & 1.613 & 68 & 81 \\
\hline
\end{tabular}

Ownership Type refers to the ownership of the Single Largest Owner 
Table A2

Summary Statistics of Performance Indicators by Extent of Ownership: 1996-1999

\begin{tabular}{|c|c|c|c|c|c|c|c|}
\hline & & Mean & $\begin{array}{c}\text { Std. } \\
\text { Dev. }\end{array}$ & Min & Max & $\begin{array}{l}\text { Num. } \\
\text { Firms }\end{array}$ & $\begin{array}{c}\text { Num. } \\
\text { Obs }\end{array}$ \\
\hline \multirow{4}{*}{$\begin{array}{l}\text { Majority } \\
\text { State }\end{array}$} & ROA & -0.013 & 0.046 & -0.154 & 0.098 & 34 & 46 \\
\hline & Profit / Sales & -0.167 & 0.906 & -2.209 & 2.415 & 44 & 58 \\
\hline & Sales & 0.017 & 0.235 & -0.880 & 0.567 & 35 & 49 \\
\hline & Labor Costs & 0.073 & 0.180 & -0.742 & 0.541 & 36 & 50 \\
\hline \multirow{4}{*}{$\begin{array}{l}\text { Majority } \\
\text { Domestic }\end{array}$} & ROA & 0.006 & 0.101 & -0.385 & 0.386 & 554 & 870 \\
\hline & Profit / Sales & -0.269 & 0.958 & -2.987 & 2.636 & 350 & 517 \\
\hline & Sales & -0.005 & 0.431 & -1.000 & 2.820 & 480 & 758 \\
\hline & Labor Costs & -0.014 & 0.406 & -1.000 & 2.732 & 553 & 880 \\
\hline \multirow{4}{*}{$\begin{array}{l}\text { Majority } \\
\text { Foreign }\end{array}$} & ROA & 0.002 & 0.084 & -0.298 & 0.257 & 111 & 185 \\
\hline & Profit / Sales & -0.234 & 0.821 & -2.967 & 2.646 & 75 & 119 \\
\hline & Sales & 0.089 & 0.360 & -1.000 & 1.707 & 99 & 165 \\
\hline & Labor Costs & 0.057 & 0.285 & -1.000 & 1.643 & 113 & 188 \\
\hline \multirow{4}{*}{$\begin{array}{l}\text { Blocking } \\
\text { Minority } \\
\text { State }\end{array}$} & ROA & -0.003 & 0.049 & -0.250 & 0.164 & 50 & 67 \\
\hline & Profit / Sales & -0.169 & 0.854 & -2.947 & 2.621 & 71 & 96 \\
\hline & Sales & 0.015 & 0.140 & -0.552 & 0.291 & 48 & 63 \\
\hline & Labor Costs & 0.077 & 0.155 & -0.682 & 0.641 & 50 & 67 \\
\hline \multirow{4}{*}{$\begin{array}{l}\text { Blocking } \\
\text { Minority } \\
\text { Domestic }\end{array}$} & ROA & -0.004 & 0.099 & -0.367 & 0.387 & 531 & 748 \\
\hline & Profit / Sales & -0.261 & 1.047 & -2.905 & 2.813 & 371 & 484 \\
\hline & Sales & -0.005 & 0.441 & -1.000 & 2.405 & 478 & 679 \\
\hline & Labor Costs & -0.021 & 0.339 & -1.000 & 2.842 & 527 & 754 \\
\hline \multirow{4}{*}{$\begin{array}{l}\text { Blocking } \\
\text { Minority } \\
\text { Foreign }\end{array}$} & ROA & -0.001 & 0.063 & -0.248 & 0.226 & 67 & 97 \\
\hline & Profit / Sales & -0.084 & 0.978 & -2.868 & 2.744 & 45 & 56 \\
\hline & Sales & 0.055 & 0.413 & -0.929 & 2.795 & 58 & 86 \\
\hline & Labor Costs & 0.094 & 0.319 & -0.765 & 1.568 & 68 & 100 \\
\hline \multirow{4}{*}{$\begin{array}{l}\text { Legal } \\
\text { Minority } \\
\text { State }\end{array}$} & ROA & -0.005 & 0.060 & -0.231 & 0.151 & 40 & 60 \\
\hline & Profit / Sales & -0.186 & 0.768 & -2.559 & 2.269 & 74 & 92 \\
\hline & Sales & 0.047 & 0.273 & -0.994 & 1.325 & 39 & 58 \\
\hline & Labor Costs & 0.094 & 0.343 & -0.989 & 2.219 & 41 & 61 \\
\hline \multirow{4}{*}{$\begin{array}{l}\text { Legal } \\
\text { Minority } \\
\text { Domestic }\end{array}$} & ROA & 0.001 & 0.108 & -0.393 & 0.387 & 483 & 743 \\
\hline & Profit / Sales & -0.330 & 1.047 & -2.995 & 2.985 & 480 & 669 \\
\hline & Sales & 0.005 & 0.471 & -1.000 & 2.726 & 437 & 656 \\
\hline & Labor Costs & 0.018 & 0.380 & -1.000 & 2.750 & 491 & 759 \\
\hline \multirow{4}{*}{$\begin{array}{l}\text { Legal } \\
\text { Minority } \\
\text { Foreign }\end{array}$} & ROA & -0.024 & 0.095 & -0.368 & 0.102 & 34 & 50 \\
\hline & Profit / Sales & -0.190 & 0.816 & -2.627 & 2.432 & 30 & 40 \\
\hline & Sales & 0.102 & 0.310 & -0.469 & 0.917 & 32 & 45 \\
\hline & Labor Costs & 0.090 & 0.276 & -0.558 & 1.613 & 34 & 49 \\
\hline \multirow{4}{*}{$\begin{array}{l}\text { Other than } \\
\text { Majority or } \\
\text { Minority }\end{array}$} & ROA & 0.015 & 0.088 & -0.248 & 0.245 & 31 & 39 \\
\hline & Profit / Sales & -0.276 & 0.739 & -1.304 & 1.619 & 33 & 44 \\
\hline & Sales & -0.059 & 0.301 & -1.000 & 0.283 & 25 & 33 \\
\hline & Labor Costs & 0.149 & 0.398 & -0.463 & 2.073 & 31 & 41 \\
\hline
\end{tabular}


Table A3

Pre-Privatization Characteristics of Firms

\begin{tabular}{|c|c|c|c|c|}
\hline Variable & Mean & Std. Dev. & Min & Max \\
\hline \multicolumn{5}{|l|}{ Panel A } \\
\hline Registered Capital (in thousands of korunas) & 419,607 & $1,877,644$ & 3,141 & $49,200,000$ \\
\hline Net Asset Value (in thousands of korunas) & 489,480 & $2,178,180$ & 3,490 & $56,000,000$ \\
\hline Total Number of Shares & 412,827 & $1,870,709$ & 3,141 & $49,200,000$ \\
\hline \multicolumn{5}{|l|}{ Number of Shares Entering Voucher } \\
\hline Privatization & 220,490 & 656,943 & 2,202 & $14,800,000$ \\
\hline \multicolumn{5}{|l|}{ Number of Shares Allocated through Voucher } \\
\hline Privatization & 204,935 & 629,464 & 1,537 & $13,800,000$ \\
\hline Value of Shares in Terms of Voucher Points & 6,903,206 & $24,200,000$ & 67,300 & $611,000,000$ \\
\hline Regions & Mean & Std.Dev. & Min & Max \\
\hline \multicolumn{5}{|l|}{ Panel B } \\
\hline Prague & $15.83 \%$. & 0.3651 & 0 & 1 \\
\hline Central Bohemia & 8.14\%.. & 0.2735 & 0 & 1 \\
\hline Southern Bohemia & 7.77\%.. & 0.2677 & 0 & 1 \\
\hline Western Bohemia & $10.28 \% .$. & 0.3038 & 0 & 1 \\
\hline Northern Bohemia & $11.32 \% .$. & 0.3169 & 0 & 1 \\
\hline Eastern Bohemia & $12.72 \% .$. & 0.3333 & 0 & 1 \\
\hline Southern Moravia & $18.71 \% .$. & 0.3902 & 0 & 1 \\
\hline Northern Moravia & $15.24 \% .$. & 0.3595 & 0 & 1 \\
\hline \multicolumn{5}{|l|}{ Industrial Sectors } \\
\hline \multicolumn{5}{|l|}{ Panel C } \\
\hline Agriculture & $18.20 \%$. & 0.3859 & 0 & 1 \\
\hline Heavy Machinery & $29.88 \% .$. & 0.4579 & 0 & 1 \\
\hline Light Machinery & $17.46 \%$. & 0.3797 & 0 & 1 \\
\hline Constructions & $13.02 \%$. & 0.3366 & 0 & 1 \\
\hline Transportation & 4.07\%.. & 0.1976 & 0 & 1 \\
\hline Trade & $9.10 \%$. & 0.2877 & 0 & 1 \\
\hline $\mathrm{R} \& \mathrm{D}$ & $1.48 \%$. & 0.1208 & 0 & 1 \\
\hline Services & $4.29 \% .$. & 0.2027 & 0 & 1 \\
\hline Financial & $0.96 \%$. & 0.0976 & 0 & 1 \\
\hline Other & $1.55 \% .$. & 0.1237 & 0 & 1 \\
\hline
\end{tabular}

Note: The number of observation is 1352 for each variable 
Table A4

Proposed Allocation of Shares Among Parties (in \%)

\begin{tabular}{lcccc}
\hline \hline Variable & Mean & Std Dev. & Min. & Max \\
\hline Foreign Owner & 1.3225 & 7.6277 & 0 & 75 \\
Domestic Owner & 3.7663 & 12.8294 & 0 & 74 \\
Restitution & 0.5222 & 3.0640 & 0 & 58 \\
Fund of National Property (Temporary) & 8.4615 & 16.6760 & 0 & 84 \\
Fund of National Property (Permanent) & 0.1709 & 2.3046 & 0 & 51 \\
Sale Through Intermediary & 2.0666 & 8.5860 & 0 & 75 \\
Municipality Transfer & 3.4379 & 13.3587 & 0 & 94 \\
Other & 3.0377 & 8.0087 & 0 & 81 \\
Total Number of Privatization Projects & 3.0178 & 7.0905 & 1 & 77 \\
\hline \hline
\end{tabular}

Note: The number of observation is 1352 for each variable 
Table A5

Performance Indicators prior to Privatization

\begin{tabular}{|c|c|c|c|c|c|c|}
\hline Variable per Share & & $\begin{array}{c}\text { No. of } \\
\text { observations }\end{array}$ & Mean & Std.Dev. & Min & Max \\
\hline \multicolumn{7}{|l|}{ Sales } \\
\hline & 3 years to privatization & 1210 & 3.6350 & 40.3716 & 0.001050 & 1297.0630 \\
\hline & 2 years to privatization & 1210 & 3.5091 & 46.8384 & 0.000000 & 1614.1270 \\
\hline & 1 year to privatization & 1346 & 2.3407 & 7.0245 & 0.001787 & 200.0090 \\
\hline \multicolumn{7}{|l|}{ Profit } \\
\hline & 3 years to privatization & 1196 & 0.2650 & 1.8867 & -1.587883 & 43.7188 \\
\hline & 2 years to privatization & 1269 & 0.3058 & 3.5251 & -2.234356 & 117.8678 \\
\hline & 1 year to privatization & 1338 & 0.1919 & 1.3306 & 10.135990 & 38.4093 \\
\hline \multicolumn{7}{|l|}{ Debt } \\
\hline & 3 years to privatization & 916 & 0.6610 & 2.0698 & 0.000249 & 31.8724 \\
\hline & 2 years to privatization & 1021 & 0.6183 & 1.8527 & 0.000121 & 38.1252 \\
\hline & 1 year to privatization & 1155 & 0.6284 & 2.1576 & 0.000092 & 32.1283 \\
\hline \multicolumn{7}{|l|}{ Employment } \\
\hline & 3 years to privatization & 1221 & 0.0061 & 0.0150 & 0.000002 & 0.4177 \\
\hline & 2 years to privatization & 1281 & 0.0057 & 0.0142 & 0.000002 & 0.3998 \\
\hline & 1 year to privatization & 1348 & 0.0050 & 0.0132 & 0.000002 & 0.3812 \\
\hline
\end{tabular}


Table A6,

First Stage Logit Regressions

Marginal Effects of the Ownership Type $(d P(x=1) / d x)$

\begin{tabular}{|c|c|c|c|c|c|c|c|c|c|c|c|c|c|c|}
\hline $\begin{array}{l}\text { Variable } \\
\text { Regional Dummies }\end{array}$ & \multicolumn{2}{|c|}{$\begin{array}{l}\text { Domestic } \\
\text { Industrial } \\
\text { Company }\end{array}$} & \multicolumn{2}{|c|}{$\begin{array}{l}\text { Domestic } \\
\text { Bank }\end{array}$} & \multicolumn{2}{|c|}{$\begin{array}{l}\text { Domestic } \\
\text { Investment } \\
\text { Fund }\end{array}$} & \multicolumn{2}{|c|}{$\begin{array}{l}\text { Domestic } \\
\text { Individual } \\
\text { Owner }\end{array}$} & \multicolumn{2}{|c|}{$\begin{array}{l}\text { Domestic } \\
\text { Portfolio } \\
\text { Company }\end{array}$} & \multicolumn{2}{|c|}{$\begin{array}{l}\text { Foreign } \\
\text { Industrial } \\
\text { Company }\end{array}$} & \multicolumn{2}{|l|}{$\begin{array}{l}\text { Foreign } \\
\text { Other } \\
\text { Owners }\end{array}$} \\
\hline Central Bohemia & 0.141 & 5 & 0.023 & & -0.124 & 10 & -0.005 & & -0.046 & & 0.182 & 1 & 0.039 & 5 \\
\hline Southern Bohemia & 0.127 & 5 & 0.000 & & -0.030 & & -0.164 & 5 & -0.039 & & 0.121 & 5 & 0.036 & 10 \\
\hline Western Bohemia & 0.050 & & 0.000 & & -0.026 & & -0.071 & 10 & 0.002 & & 0.149 & 5 & 0.017 & \\
\hline Eastern Bohemia & 0.084 & & 0.003 & & -0.091 & 10 & -0.026 & & -0.020 & & 0.082 & & 0.028 & \\
\hline Southern Moravia & 0.130 & 5 & 0.015 & & -0.076 & 10 & -0.026 & & -0.016 & & 0.113 & 10 & -0.007 & \\
\hline \multicolumn{15}{|l|}{ Intended Ownership (percent) } \\
\hline Foreign Owner & -0.011 & 1 & 0.000 & & -0.005 & & 0.000 & & 0.000 & & 0.000 & & 0.000 & \\
\hline Domestic Owner & 0.004 & 1 & 0.002 & 1 & -0.004 & 10 & 0.000 & & 0.001 & & -0.004 & 1 & 0.000 & \\
\hline Restitution & 0.014 & & 0.004 & & -0.002 & & -0.009 & & -0.014 & & 0.004 & & 0.000 & \\
\hline Fund of National Property (Temporary) & -0.002 & & 0.001 & 5 & -0.003 & 10 & -0.001 & & 0.001 & 10 & -0.002 & 5 & 0.001 & 5 \\
\hline Sale Through Intermediary & 0.002 & & 0.000 & & 0.003 & 10 & 0.000 & & 0.000 & & -0.003 & 1 & 0.001 & \\
\hline Municipality Transfer & -0.025 & 1 & 0.000 & & -0.002 & & -0.005 & & 0.000 & & -0.002 & 5 & 0.001 & 5 \\
\hline Other & 0.008 & 1 & 0.000 & & -0.007 & & -0.011 & 5 & 0.001 & & -0.004 & 1 & -0.003 & \\
\hline \multicolumn{15}{|l|}{ Quantitative Privatization Characteristics } \\
\hline Privatized in Voucher Scheme & 0.000 & & 0.001 & 1 & 0.004 & 5 & 0.001 & & 0.001 & & -0.005 & 1 & 0.002 & 1 \\
\hline Total Number of Privatization Projects & 0.005 & 1 & 0.001 & 1 & 0.002 & 10 & -0.001 & & -0.003 & & -0.001 & & -0.021 & \\
\hline Total Number of Shares (mil.) & 0.088 & & 0.053 & 5 & 0.166 & & 0.365 & & -0.142 & & -0.214 & 5 & 0.140 & 5 \\
\hline Total Number of Shares (mil.) [Squared] & -0.003 & & -0.005 & & -0.084 & 1 & -0.125 & & -0.033 & & -0.042 & & -0.014 & 10 \\
\hline $\begin{array}{l}\text { Total Number of Shares in the Voucher Scheme } \\
\text { (mil.) }\end{array}$ & -0.048 & & -0.168 & & -0.001 & & 0.109 & & -0.448 & & 0.050 & & -0.512 & 10 \\
\hline Sold Shares (mil.) & -0.025 & & 0.135 & & 0.197 & & -0.653 & & 0.730 & & 0.312 & & 0.402 & 10 \\
\hline Sold Points (mil.) & -0.002 & & 0.583 & & -0.005 & 5 & -0.302 & & -0.004 & 10 & 0.003 & 5 & 0.216 & \\
\hline Share Average Price in Voucher Scheme & 0.000 & & 0.000 & & 0.002 & 5 & -0.001 & & 0.001 & 10 & 0.000 & & 0.000 & \\
\hline Share Average Price in Voucher Scheme [Squared] & 0.000 & & 0.000 & & 0.000 & & 0.000 & & 0.000 & 10 & 0.000 & & 0.000 & \\
\hline Constant & -0.433 & & -0.206 & 5 & -0.432 & & -0.131 & & -0.164 & & 0.175 & & -0.289 & 1 \\
\hline
\end{tabular}

Number 1, 5 and 10 denote significance at 1\%,5\% and 10\% level, two-tail test, respectively. 
Table A7

First Stage Logit Regressions

Marginal Effects of the Ownership Size $(d P(x=1) / d x)$

\begin{tabular}{|c|c|c|c|c|c|c|c|c|c|c|c|c|c|c|c|c|c|c|}
\hline Variable & $\begin{array}{l}\text { Major } \\
\text { Domes }\end{array}$ & & $\begin{array}{l}\text { Majori } \\
\text { Foreig }\end{array}$ & & $\begin{array}{c}\text { Blocking } \\
\text { Minority } \\
\text { State }\end{array}$ & & $\begin{array}{l}\text { cking } \\
\text { nority } \\
\text { mestic }\end{array}$ & & $\begin{array}{l}\text { cking } \\
\text { hority } \\
\text { ceign }\end{array}$ & & $\begin{array}{l}\text { Legal } \\
\text { Minority } \\
\text { State }\end{array}$ & & $\begin{array}{l}\text { Legal } \\
\text { Minority } \\
\text { omestic }\end{array}$ & & $\begin{array}{l}\text { Legal } \\
\text { Minority } \\
\text { Foreign }\end{array}$ & \multicolumn{3}{|c|}{$\begin{array}{c}\text { Other than } \\
\text { Majority or } \\
\text { Minority }\end{array}$} \\
\hline \multicolumn{19}{|l|}{ Regional Dummies } \\
\hline Prague & -0.138 & 1 & 0.147 & 1 & -0.033 & & 0.089 & 10 & 0.054 & 5 & 0.045 & 10 & -0.084 & & -0.054 & & 0.000 & \\
\hline Central Bohemia & -0.092 & 10 & 0.118 & 1 & -0.006 & & 0.063 & & 0.082 & 1 & 0.000 & & -0.019 & & 0.000 & & -0.01 & \\
\hline Southern Bohemia & -0.042 & & 0.038 & & 0.000 & & -0.006 & & 0.080 & 1 & 0.06 & 5 & -0.043 & & 0.000 & & 0.000 & C \\
\hline Western Bohemia & -0.186 & 1 & 0.075 & 5 & 0.051 & 5 & 0.141 & 5 & 0.081 & 1 & 0.047 & & -0.031 & & -0.002 & & 0.000 & \\
\hline Northern Bohemia & -0.096 & 10 & 0.096 & 1 & 0.05 & 5 & 0.040 & & 0.058 & 5 & 0.04 & & -0.005 & & 0.037 & 1 & 0.000 & \\
\hline Eastern Bohemia & -0.046 & & 0.073 & 10 & 0.049 & 5 & 0.069 & & 0.021 & & 0.063 & 5 & -0.079 & & 0.000 & & 0.01 & \\
\hline $\begin{array}{l}\text { Southern Moravia } \\
\text { Intended Ownership (percent) }\end{array}$ & -0.101 & 5 & 0.000 & & 0.034 & & 0.180 & 1 & 0.000 & & 0.052 & 5 & -0.111 & 5 & 0.01 & & 0.005 & \\
\hline Foreign Owner & -0.001 & & 0.003 & 1 & 0.000 & & 0.000 & & 0.002 & 1 & 0.000 & & -0.008 & 5 & 0.000 & & 0.000 & \\
\hline Domestic Owner & 0.003 & 5 & -0.002 & 1 & 0.001 & 5 & 0.002 & & -0.001 & & -0.001 & & 0.000 & & -0.001 & & 0.001 & \\
\hline Restitution & 0.013 & 10 & 0.000 & & 0.000 & & -0.007 & & 0.001 & & 0.002 & & -0.003 & & 0.004 & 5 & 0.000 & \\
\hline $\begin{array}{l}\text { Fund of National Property } \\
\text { (Temporary) }\end{array}$ & 0.000 & & -0.001 & 10 & 0.002 & 1 & 0.004 & 5 & 0.001 & 0 & -0.001 & & -0.007 & 1 & 0.002 & 1 & 0.000 & \\
\hline $\begin{array}{l}\text { Fund of National Property } \\
\text { (Permanent) }\end{array}$ & -0.022 & & -0.001 & & 0.001 & & 0.019 & 10 & 0.000 & & 0.000 & & -0.009 & & 0.000 & & 0.000 & \\
\hline Sale Through Intermediary & 0.004 & 5 & 0.000 & & 0.000 & & 0.004 & 5 & 0.000 & & -0.004 & & -0.003 & & 0.001 & 10 & 0.000 & \\
\hline Municipality Transfer & -0.013 & 10 & -0.001 & & 0.001 & 10 & -0.003 & & 0.000 & & 0.001 & & -0.007 & 5 & 0.001 & & -0.002 & \\
\hline Other & 0.006 & 1 & -0.013 & 1 & 0.001 & & 0.001 & & 0.000 & & -0.001 & & -0.005 & 10 & 0.001 & & -0.008 & 5 \\
\hline
\end{tabular}


Quantitative Privatization Characteristics

Privatized in Voucher Scheme $\quad 0.00$

Total Number of Privatization

0.002

$-0.001$

Projects

$\begin{array}{llll}0.004^{5} & -0.001 & 0.000\end{array}$

$\begin{array}{lll}0.004 & 1 & 0.000\end{array}$

Total Number of Shares (mil.)

$\begin{array}{lll}0.407 \quad 1 & 0.146\end{array}$

0.005

$-0.005$

0.001

Total Number of Shares (mil.)

[Squared]

Total Number of Shares in the

Voucher Scheme (mil.)

$-0.050 \quad 1 \quad-0.061$

0.060

$-0.079$

$-0.007$

$-1.388^{5}-0.148$

$-0.064$

0.002

$-0.375$

Sold Shares (mil.)

Sold Points (mil.)

$0.715 \quad 0.017$

$-0.064$

0.022

0.064

$-0.386$

0.017

$-0.149$

$-0.011$

Share Average Price in Voucher

Scheme

$-0.001$

0.001

0.000

0.566

$-0.647$

$\begin{array}{rr}-0.647 & \\ 0.673 & 10\end{array}$

0.673
0.581

$-0.001$

Share Average Price in Voucher

Scheme [Squared]

$\begin{array}{lll}0.000 & 0.000 & 5\end{array}$

0.000

0.001

Constant

Pre-privatization Characteristics

$-0.264$

$-0.042$

$-0.224$

$10 \quad-0.680$

$10 \quad 0.000-10$

1

0.000

$-0.108$

R-square

yes

yes

yes

yes

$-0.078$

yes

yes
0.317

0.2

0.317

Number 1, 5 and 10 denote significance at 1\%, 5\% and 10\% level, two-tail test, respectively. 


\section{Table A8}

Effect of the Single Largest Owner (SLO) Type on Performance

OLS First-differences Estimates (Standard errors in parentheses)

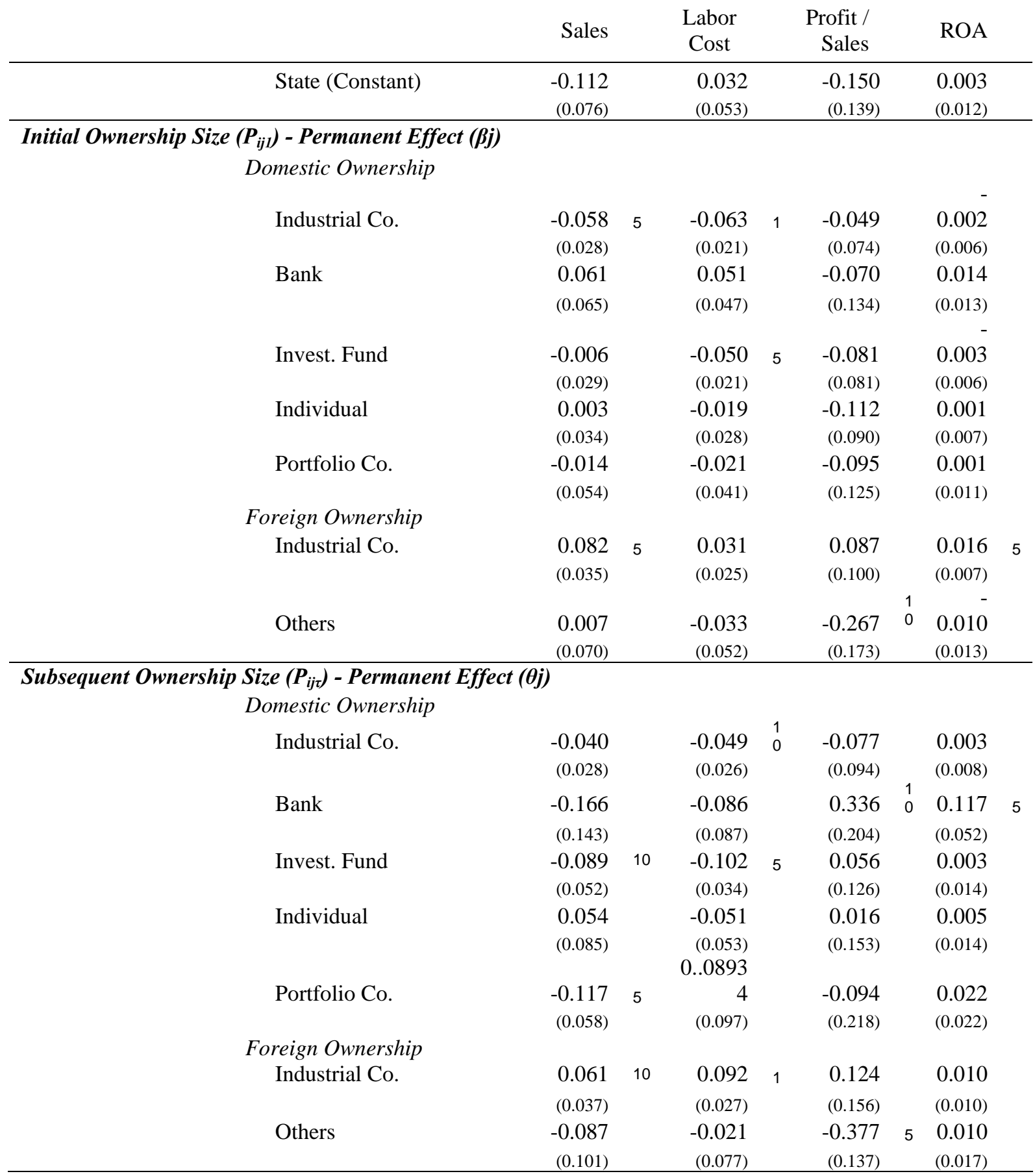


Ownership Change $\left(\Delta P_{i j \tau}\right)$ - Instantaneous Effect ( $\left.\delta j\right)$

Domestic Ownership

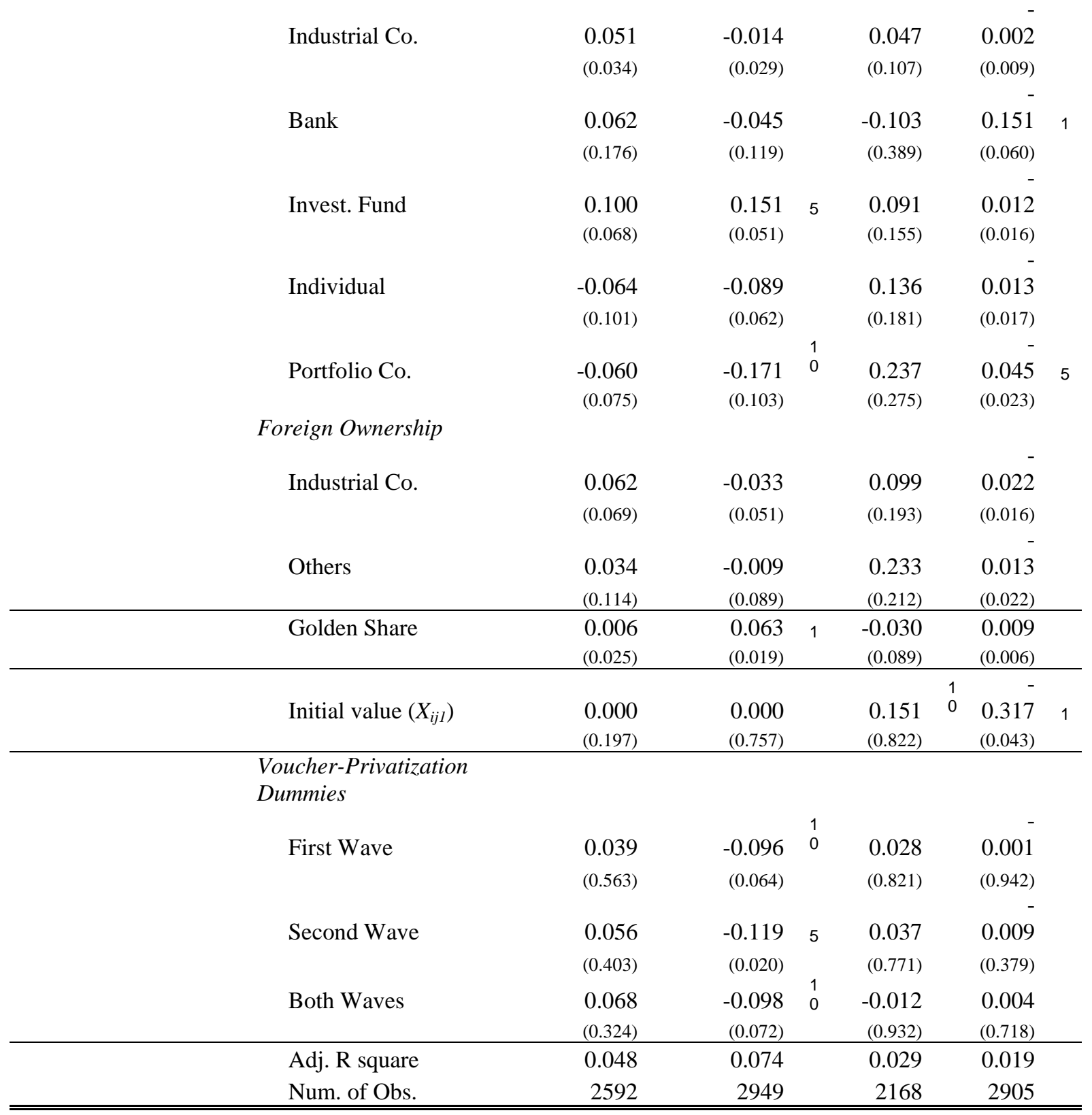

Note: The dependent variables are the rate of change of sales revenue, labor cost, and profit/sales, and the change in ROA, respectively. Numbers in parentheses are standard errors. Number 1, 5 and 10 denote significance at $1 \%, 5 \%$ and $10 \%$ level, two-tail test, respectively. Industry, privatization, and year dummies are included. 
Table A9

Effect of Ownership Extent on Performance

OLS First-differences Estimates (Standard errors in parentheses)

\begin{tabular}{|c|c|c|c|c|c|c|c|c|}
\hline & Sales & & $\begin{array}{r}\text { Labor } \\
\text { Cost }\end{array}$ & & $\begin{array}{r}\text { Profit / } \\
\text { Sales } \\
\end{array}$ & & \multicolumn{2}{|l|}{ ROA } \\
\hline \multirow[t]{2}{*}{ Majority State (Constant) } & -0.115 & & 0.003 & & -0.175 & & -0.002 & \\
\hline & $(0.085)$ & & $(0.054)$ & & $(0.176)$ & & $(0.014)$ & \\
\hline \multicolumn{9}{|l|}{ Initial Ownership Size $\left(P_{i j 1}\right)$ - Permanent Effect $(\beta j)$} \\
\hline \multirow[t]{2}{*}{ Majority Domestic } & -0.054 & & -0.051 & 10 & -0.050 & & 0.007 & \\
\hline & $(0.055)$ & & $(0.031)$ & & $(0.134)$ & & $(0.010)$ & \\
\hline \multirow[t]{2}{*}{ Majority Foreign } & 0.076 & & 0.037 & & -0.021 & & 0.021 & 10 \\
\hline & $(0.063)$ & & $(0.037)$ & & $(0.151)$ & & $(0.011)$ & \\
\hline \multirow[t]{2}{*}{ Blocking Minority State } & -0.031 & & 0.009 & & -0.114 & & 0.008 & \\
\hline & $(0.056)$ & & $(0.030)$ & & $(0.154)$ & & $(0.011)$ & \\
\hline \multicolumn{9}{|l|}{ Blocking Minority } \\
\hline \multirow[t]{2}{*}{ Domestic } & -0.058 & & -0.029 & & -0.062 & & -0.003 & \\
\hline & $(0.054)$ & & $(0.029)$ & & $(0.136)$ & & $(0.010)$ & \\
\hline \multirow[t]{2}{*}{ Blocking Minority Foreign } & -0.020 & & -0.001 & & 0.085 & & 0.011 & \\
\hline & $(0.062)$ & & $(0.038)$ & & $(0.219)$ & & $(0.014)$ & \\
\hline \multirow[t]{2}{*}{ Legal Minority State } & -0.049 & & 0.001 & & 0.006 & & -0.005 & \\
\hline & $(0.059)$ & & $(0.038)$ & & $(0.155)$ & & $(0.012)$ & \\
\hline \multirow[t]{2}{*}{ Legal Minority Domestic } & -0.049 & & -0.021 & & -0.148 & & -0.001 & \\
\hline & $(0.054)$ & & $(0.029)$ & & $(0.133)$ & & $(0.010)$ & \\
\hline \multirow[t]{2}{*}{ Legal Minority Foreign } & -0.328 & & 0.050 & & -0.095 & & -0.006 & \\
\hline & $(0.069)$ & & $(0.054)$ & & $(0.206)$ & & $(0.015)$ & \\
\hline \multirow[t]{2}{*}{$\begin{array}{l}\text { Other than Majority or } \\
\text { Minority }\end{array}$} & 0.172 & 10 & 0.084 & 10 & 0.090 & & -0.001 & \\
\hline & $(0.105)$ & & $(0.051)$ & & $(0.177)$ & & $(0.015)$ & \\
\hline \multicolumn{9}{|l|}{ Subsequent Ownership Size $\left(P_{i j \tau}\right)$ - Permanent Effect $(\theta j)$} \\
\hline \multirow[t]{2}{*}{ Majority Domestic } & -0.026 & & -0.019 & & 0.153 & 10 & 0.016 & 10 \\
\hline & $(0.039)$ & & $(0.036)$ & & $(0.093)$ & & $(0.009)$ & \\
\hline \multirow[t]{2}{*}{ Majority Foreign } & 0.083 & 10 & 0.027 & & -0.152 & & 0.009 & \\
\hline & $(0.049)$ & & $(0.028)$ & & $(0.160)$ & & $(0.019)$ & \\
\hline \multirow[t]{2}{*}{ Blocking Minority State } & -0.128 & & -0.141 & & 0.726 & & -0.050 & \\
\hline & $(0.099)$ & & $(0.100)$ & & $(0.501)$ & & $(0.061)$ & \\
\hline $\begin{array}{l}\text { Blocking Minority } \\
\text { Domestic }\end{array}$ & & 10 & , & 10 & 0017 & & 0 & \\
\hline 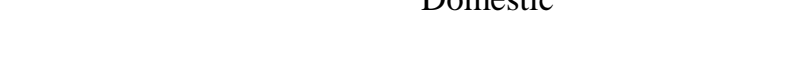 & $\begin{array}{r}-0.035 \\
(0.034)\end{array}$ & & $\begin{array}{r}-0.044 \\
(0.027)\end{array}$ & & $(0.094)$ & & $(0.008)$ & \\
\hline \multirow[t]{2}{*}{ Blocking Minority Foreign } & 0.044 & & 0.045 & & 0.093 & & 0.015 & 10 \\
\hline & $(0.084)$ & & $(0.040)$ & & $(0.157)$ & & $(0.009)$ & \\
\hline \multirow[t]{2}{*}{ Legal Minority State } & -0.127 & 10 & 0.353 & & 0.560 & 5 & -0.024 & \\
\hline & $(0.074)$ & & $(0.280)$ & & $(0.249)$ & & $(0.031)$ & \\
\hline \multirow[t]{2}{*}{ Legal Minority Domestic } & 0.004 & & -0.020 & & 0.024 & & 0.018 & \\
\hline & $(0.045)$ & & $(0.280)$ & & $(0.127)$ & & $(0.009)$ & \\
\hline \multirow[t]{2}{*}{ Legal Minority Foreign } & -0.156 & 10 & -0.017 & & -0.029 & & -0.007 & \\
\hline & $(0.090)$ & & $(0.033)$ & & $(0.160)$ & & $(0.021)$ & \\
\hline \multirow[t]{2}{*}{$\begin{array}{l}\text { Other than Majority or } \\
\text { Minority }\end{array}$} & -0.354 & 10 & 0.442 & 10 & 0.453 & & 0.070 & \\
\hline & $(0.217)$ & & $(0.241)$ & & $(0.439)$ & & $(0.061)$ & \\
\hline
\end{tabular}


Ownership Change $\left(\Delta P_{i j \tau}\right)$ - Instantaneous Effect (סj)

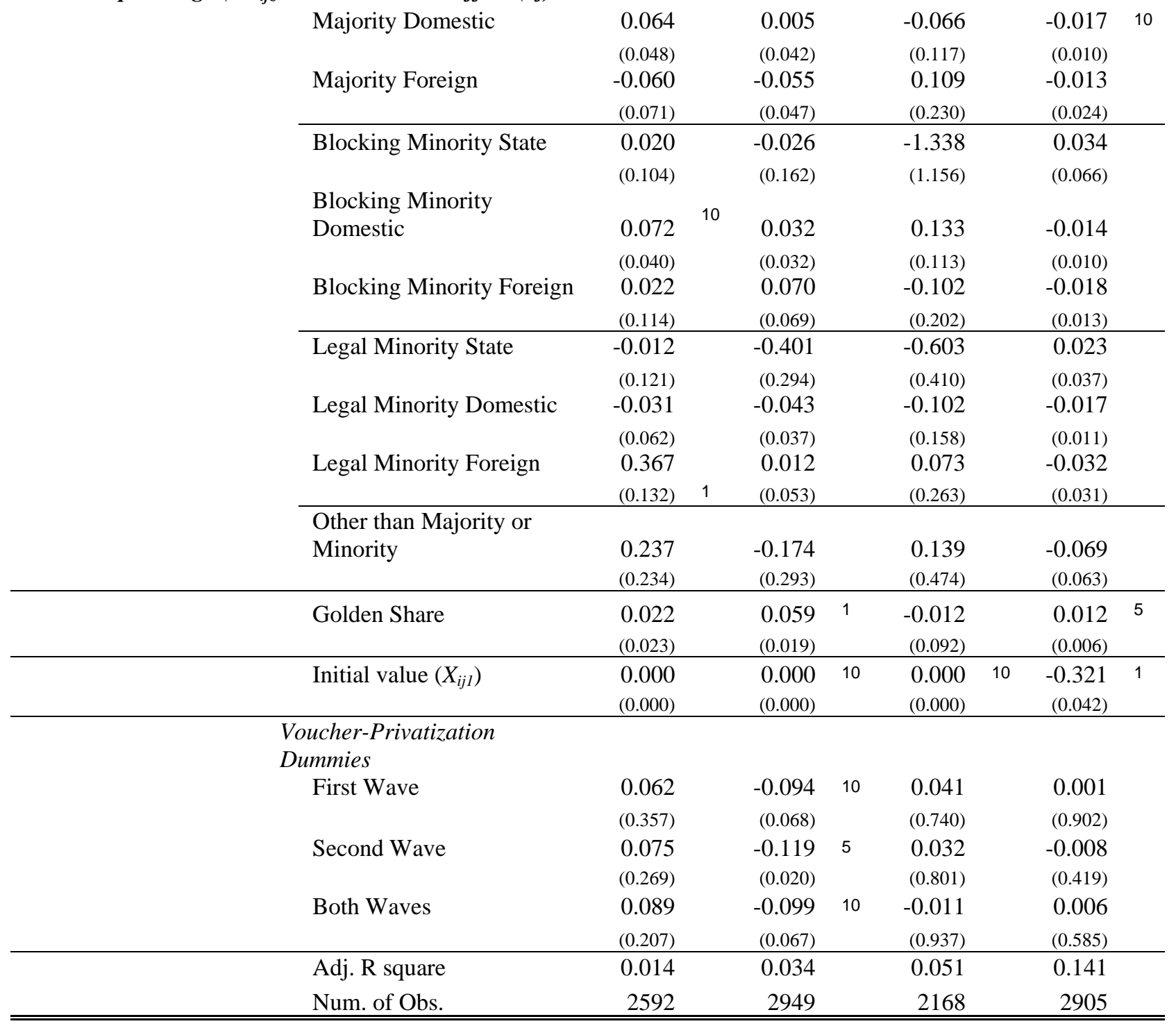

Note: The dependent variables are the rate of change of sales revenue, labor cost, and profit/sales, and the change in ROA, respectively. Numbers in parentheses are standard errors. Number 1, 5 and 10 denote significance at 1\%, 5\% and $10 \%$ level, two-tail test, respectively. Industry, privatization, and year dummies are included. 
Individual researchers, as well as the on-line and printed versions of the CERGE-EI Working Papers (including their dissemination) were supported from the following institutional grants:

- Economic Aspects of EU and EMU Entry [Ekonomické aspekty vstupu do Evropské unie a Evropské měnové unie], No. AVOZ70850503, (2005-2010);

- Economic Impact of European Integration on the Czech Republic [Ekonomické dopady evropské integrace na ČR], No. MSM0021620846, (2005-2011);

Specific research support and/or other grants the researchers/publications benefited from are acknowledged at the beginning of the Paper.

(c) Jan Hanousek, Evžen Kočenda, Jan Švejnar, 2005

All rights reserved. No part of this publication may be reproduced, stored in a retrieval system or transmitted in any form or by any means, electronic, mechanical or photocopying, recording, or otherwise without the prior permission of the publisher.

Published by

Charles University in Prague, Center for Economic Research and Graduate Education (CERGE) and

Economics Institute (EI), Academy of Sciences of the Czech Republic

CERGE-El, Politických vězñu 7, 11121 Prague 1, tel.: +420 224005 153, Czech Republic.

Printed by CERGE-EI, Prague

Subscription: CERGE-El homepage: http://www.cerge-ei.cz

Editors: Directors of CERGE and EI

Managing editors: Deputy Directors for Research of CERGE and EI

ISSN 1211-3298

ISBN 80-7343-048-7 (Univerzita Karlova v Praze, CERGE)

ISBN 80-7344-037-7 (Národohospodářský ústav AV ČR, Praha) 
CERGE-EI

P.O.BOX 882

Politických vězňů 7

11121 Praha 1

Czech Republic http://www.cerge-ei.cz 